\title{
Chemotrophic Microbial Mats and Their Potential for Preservation in the Rock Record
}

\author{
Jake V. Bailey, ${ }^{1}$ Victoria J. Orphan, Samantha B. Joye, ${ }^{2}$ and Frank A. Corsetti ${ }^{3}$
}

\begin{abstract}
Putative microbialites are commonly regarded to have formed in association with photosynthetic microorganisms, such as cyanobacteria. However, many modern microbial mat ecosystems are dominated by chemotrophic bacteria and archaea. Like phototrophs, filamentous sulfur-oxidizing bacteria form large mats at the sediment/ water interface that can act to stabilize sediments, and their metabolic activities may mediate the formation of marine phosphorites. Similarly, bacteria and archaea associated with the anaerobic oxidation of methane (AOM) catalyze the precipitation of seafloor authigenic carbonates. When preserved, lipid biomarkers, isotopic signatures, body fossils, and lithological indicators of the local depositional environment may be used to identify chemotrophic mats in the rock record. The recognition of chemotrophic communities in the rock record has the potential to transform our understanding of ancient microbial ecologies, evolution, and geochemical conditions. Chemotrophic microbes on Earth occupy naturally occurring interfaces between oxidized and reduced chemical species and thus may provide a new set of search criteria to target life-detection efforts on other planets. Key Words: Carbonates-Chemolithotrophic microorganisms-Methane-Phosphorites-Stromatolites. Astrobiology 9, 843-859.
\end{abstract}

\section{Introduction}

$\mathbf{S}$ EDIMENTARY STRUCTURES SUCH AS STROMATOLITES were argued to represent fossilized plant or algal material more than a century ago (Walcott, 1883; Matthew, 1890). These interpretations were controversial until modern cyanobacterial mats associated with recent stromatolites were shown to trap and bind sedimentary grains and precipitate authigenic minerals, after which stromatolite biogenicity became widely accepted (Logan, 1961; Dravis, 1983; Dill et al., 1986; Reid et al., 2000). Lithification, which is critical for the preservation of mats in carbonate rocks, had also been linked to metabolic processes, such as dissimilatory sulfate reduction, that occur in layered mat communities (Chafetz and Buczynski, 1992; Visscher et al., 2000; Paerl et al., 2001; Dupraz and Visscher, 2005; Ludwig et al., 2005). Stromatolites are known from a variety of depositional settings, and their record dates back to the Archean, where they are commonly regarded as traces of Earth's early microbial biosphere (Walter et al., 1980; Buick, 1984; Hofmann et al., 1999; Allwood et al., 2006).

Although stromatolites are commonly interpreted as biogenic structures, it is now known that some stromatolites can form in the absence of microbial involvement (Lowe, 1994;
Grotzinger and Knoll, 1999; McLoughlin et al., 2008). Microbes may well be involved in many, if not most, stromatolites, but the lamination, doming, and branching commonly associated with stromatolites can also form in the absence of biology. A similar misconception is that cyanobacteria are the primary organisms involved in putative microbialite morphogenesis-again because of their connate association in modern environments. However, cyanobacteriadominated mats are not the only mat ecosystems that can stabilize sediments and mediate authigenic mineral precipitation (e.g., Golubic, 1976; Williams and Reimers, 1983; Pierson et al., 1992; Krajewski et al., 1994; Soudry, 2000; Bailey et al., 2006; Trela, 2008). Here, we present a review of modern chemotrophic mats, as well as ancient sedimentary features that may have formed in association with such mats. Certain chemotrophic microbes, such as those described here, possess many of the same attributes that influence sediment trapping and binding by cyanobacteria-including mat formation, large size, vertically-oriented motility, and the production of extracellular polymeric substances (e.g., Schulz and Jørgensen, 2001; Teske and Nelson, 2006; Mußmann et al., 2007). Furthermore, many chemotrophdominated mat communities influence the local geochemical

\footnotetext{
${ }^{1}$ Division of Geological and Planetary Sciences, California Institute of Technology, Pasadena, California.

${ }^{2}$ Department of Marine Sciences, University of Georgia, Athens, Georgia.

${ }^{3}$ Department of Earth Sciences, University of Southern California, Los Angeles, California.
} 
conditions in such a way as to promote the precipitation of carbonates and phosphorites that may preserve textural or body fossil evidence of microbial mat communities in the rock record. Finally, we discuss the potential significance of nonphotosynthetic mat communities for the search for life on other planets.

\section{Extant Chemotroph-Dominated Microbial Mats}

\section{Chemolithotrophs}

Chemolithotrophs comprise a phylogenetically diverse group of microbes that can obtain all the energy required for growth from the oxidation of inorganic compounds such as $\mathrm{H}_{2}, \mathrm{H}_{2} \mathrm{~S}$, and reduced metals (Kelly, 1971; Garrity, 2005; Rabus et al., 2006; Robertson and Kuenen, 2006). Although chemolithotrophs often have low growth yields compared to phototrophs, conditions that facilitate their growth, such as gradational interfaces between electron acceptors and reduced inorganic compounds, result in the production of a high biomass that commonly takes the form of mats at, or beneath, the sediment/water interface (Larkin et al., 1994; Fossing et al., 1995; Schulz et al., 1999). Perhaps the most conspicuous of the mat-forming chemolithotrophs are the colorless sulfur bacteria, $\gamma$-proteobacteria, which include the genera Beggiatoa, Thioploca, Thiothrix, and Thiomargarita (Fig. $1 \mathrm{a}-\mathrm{c})$. These organisms obtain energy from the oxidation of reduced sulfur species, such as $\mathrm{H}_{2} \mathrm{~S}, \mathrm{~S}^{0}$, polysulfides, tetrathionates, or $\mathrm{S}_{2} \mathrm{O}_{3}^{2-}$, to $\mathrm{SO}_{4}^{2-}$ using $\mathrm{O}_{2}$ or $\mathrm{NO}_{3}^{-}$(Nelson and Castenholz, 1981; Larkin and Strohl, 1983; Wood and Kelly, 1986; Steudel et al., 1987; Kelly, 1988a, 1988b; Wentzien et al., 1994; Schulz et al., 1999; Schulz and Jørgensen, 2001; Robertson and Kuenen, 2006; Schulz, 2006; Teske and Nelson, 2006). Some members of this clade are true autotrophs, which fix carbon from $\mathrm{CO}_{2}$ using the RuBisCO enzyme, while others (known as mixotrophs) use organic compounds as a sole or supplemental source of cell carbon (Nelson and Castenholz, 1981; Nelson and Jannasch, 1983; Teske and Nelson, 2006).

Beggiatoa spp. are gliding filamentous bacteria whose morphology closely resembles filamentous cyanobacteria (Fig. 1a)—so much so that many early workers regarded Beggiatoa as an unpigmented cyanobacterium, dubbed Oscillatoria alba (Vaucher, 1803; Kolkwitz, 1909). Lacustrine Beggiatoa occur as thin non-vacuolate filaments, while marine Beggiatoa include both small-diameter, non-vacuolate strains and very large, vacuolated ecotypes (Teske and Nelson, 2006). Beggiatoa filament lengths can range from a few microns to $>10 \mathrm{~cm}$, while filament diameters can range from $1 \mu \mathrm{m}$ to over $200 \mu \mathrm{m}$. Although Beggiatoa are metabolically and phylogenetically distant from cyanobacteria (Reichenbach et al., 1986), recent genome analysis results suggest that horizontal gene transfer may be responsible for the shuffling of genes that may be involved in gliding motility, filament formation, and s-layer production between these two groups-perhaps as a result of frequent cohabitation in mat ecosystems (Mußmann et al., 2007). The chemotactic motility of the Beggiatoa allows them to thrive in sulfidic sediments associated with lakes, springs, wetlands, eutrophic bays, marine oxygen minimum zones, hydrocarbon seeps, whale falls, mud volcanoes, hydrothermal vents, and deep-sea brine pools (Jørgensen, 1977; Strohl and Larkin, 1978; Jannasch et al., 1989; Smith et al., 1989; Larkin et al.,
1994; Graco et al., 2001; Knittel et al., 2003; Nikolaus et al., 2003; Kalanetra et al., 2005). Large filamentous sulfuroxidizing Thiothrix and "White Point vacuolate bacteria" can resemble marine Beggiatoa and can be found in similar habitats, though they are generally present as forms attached to hard substrates (Howarth et al., 1999; Kalanetra et al., 2004; Teske and Nelson, 2006).

Thioploca spp. (Fig. 1b) resemble Beggiatoa but occur as a bundle of filaments within a common polysaccharide sheath (Maier and Gallardo, 1984; Teske and Nelson, 2006). These organisms glide vertically between sulfidic sediments and nitrate-containing waters at the sediment/water interface (Hüttel et al., 1996). Benthic accumulations of Thioploca occur along $3,000 \mathrm{~km}$ of the continental shelf off South America and in association with other oxygen minimum zone settings globally, which constitute perhaps the largest microbial mat ecosystem on Earth (Gallardo, 1977; Fossing et al., 1995; Schulz et al., 1996).

Thiomargarita namibiensis, a close relative of marine Beggiatoa and Thioploca strains, appears as a nonmotile vacuolated spherical bacterium that can reach $750 \mu \mathrm{m}$ in diameter (Fig. 1c). Thiomargarita from off the coast of Namibia occurs as long chains (Schulz et al., 1999), while similar bacteria from the Gulf of Mexico occur as individual cells that undergo reductive cell division that results in symmetrical cell clusters (Kalanetra et al., 2005). Thiomargarita is found in sulfidic sediments beneath upwelling zones and near methane seeps and deep marine brine pools (Schulz et al., 1999; Kalanetra et al., 2005).

The factors that regulate the distribution of sulfur-oxidizing microbial mats are poorly understood. Concentrations of hydrogen sulfide, oxygen and nitrate content of the overlying water, methane seepage intensity, and AOM/sulfatereduction activity in the underlying sediment pore waters are likely factors that regulate distribution and metabolic rates in sulfur-oxidizing microbial mats (Joye et al., 2004, 2009b). At hydrocarbon seeps, seepage intensity and sulfate reduction rates vary substantially, and this drives spatial and temporal variability in composition and density of the sulfide-oxidizing bacteria in the overlying mats and in the metabolic activity rates in the underlying sediment (Joye et al., 2009a). Mats of sulfide-oxidizing bacteria are also common in oxygen minimum zone sediments where sulfide production is fueled by anaerobic respiration of abundant phytodetritus.

Along the Costa Rica Margin, in the Gulf of Mexico, and elsewhere, mats of orange Beggiatoa, white Beggiatoa, or both are a striking seafloor feature (Fig. 2a-e). In seep settings, such mats can be used as indicators of active seepage (e.g., Tryon and Brown, 2001; Joye et al., 2004; Teichert et al., 2005). In sulfidic environments, Beggiatoa mats blanket dark, reducing, $\mathrm{H}_{2} \mathrm{~S}$-rich sediments (Fig. 2d). In the Gulf of Mexico, the interface between brown oxidized sediments and matinhabited reducing sediments is often sharp (Fig. 2c). Similarly, boundaries between orange versus white Beggiatoa can be quite sharp. Sediment cores collected along a horizontal transect from brown oxidizing sediment to dense white and then orange Beggiatoa mats (Fig. 2c) indicate that $\mathrm{H}_{2} \mathrm{~S}$ concentration was highest beneath the orange Beggiatoa mats compared to white Beggiatoa mats or brown sediments (Joye et al., 2009b). Because orange Beggiatoa may benefit from mixotrophic metabolism and white Beggiatoa appear to be 

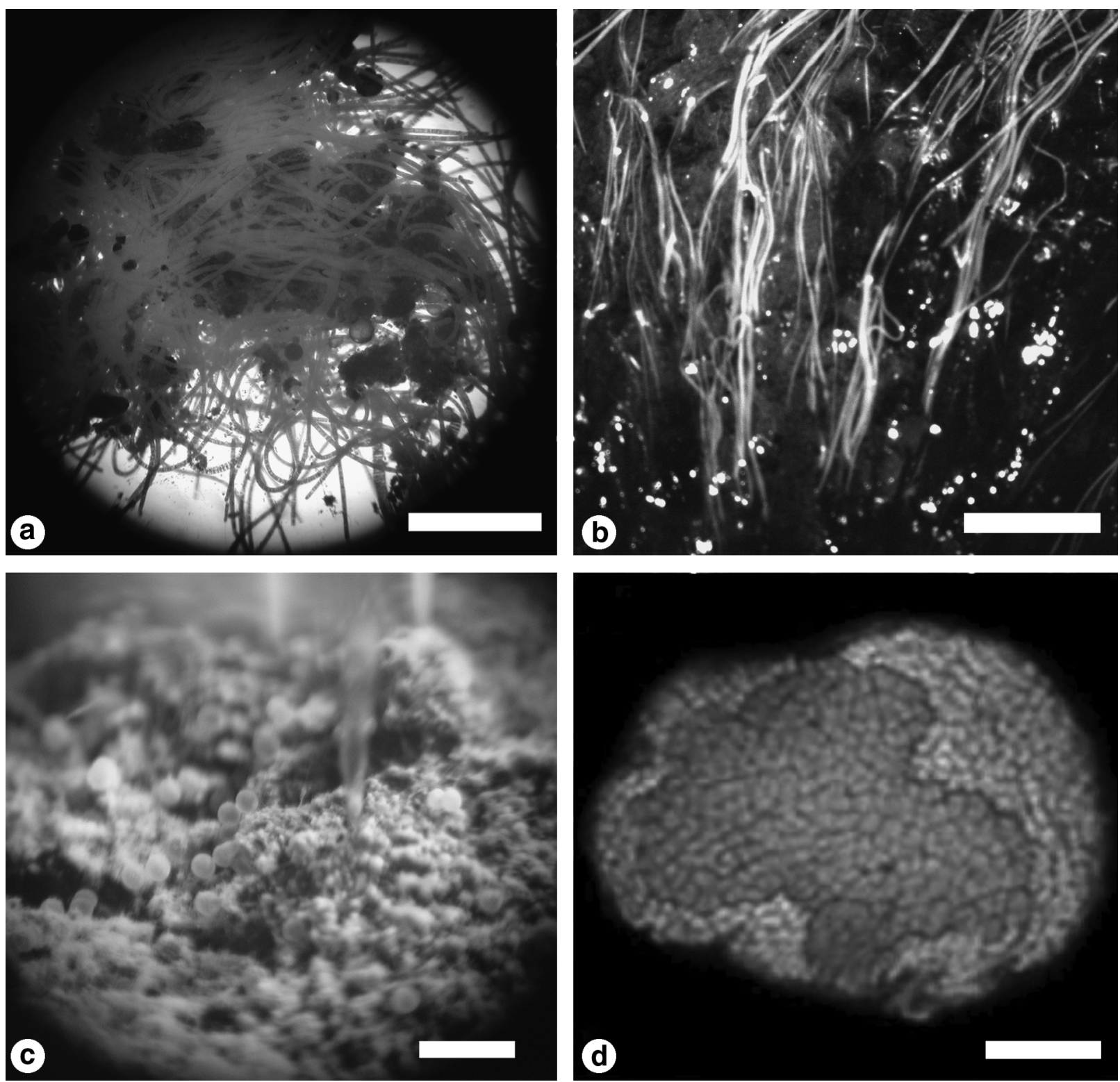

FIG. 1. Mat-forming chemotrophs. (a) Beggiatoa occurs as large, motile, septate filaments. In the mass of marine Beggiatoa filaments, the largest filaments are approximately $200 \mu \mathrm{m}$ in diameter, while the smaller ones are about 50-75 $\mu \mathrm{m}$ in diameter. Scale bar $=\sim 2 \mathrm{~mm}$. (b) Thioploca spp. occurs as a bundle of septate filaments (ca. 30-70 $\mu \mathrm{m}$ in diameter), similar to Beggiatoa but surrounded by a common sheath (ca. 100-200 $\mu \mathrm{m}$ in diameter). Scale bar $=\sim 0.5 \mathrm{~cm}$. Photo contributed by Heide SchulzVogt. (c) Spherical Thiomargarita cells are the largest in the bacterial world. A thin layer of cytoplasm surrounds an immense single vacuole. Scale bar $=\sim 1.5 \mathrm{~mm}$. (d) Archaea and bacteria involved in the anaerobic oxidation of methane commonly occur in spherical aggregates consisting of a core of hundreds of archaeal cells surrounded by a shell of sulfate-reducing bacteria (after Orphan et al., 2004). Scale bar $=10 \mu \mathrm{m}$.

strict autotrophs (Nikolaus et al., 2003) differences in organic carbon availability may also contribute to spatial variation in white versus orange Beggiatoa abundance. Some sediments overlain by less dense Beggiatoa mats or mixed Beggiatoa/ Thiomargarita mats contain lower concentrations of hydrogen sulfide (0.5-2 $\mathrm{mM} \mathrm{H}_{2} \mathrm{~S}$; Joye, unpublished data). At hydrocarbon seeps, sulfide is produced by sulfate reduction coupled to the oxidation of methane, as well as nonmethane-dependent sulfate reduction, that in some cases utilizes longer-chain hydrocarbons; and the distributions of mat-forming sulfur bacteria that oxidize the resulting sulfide can be correlated with seep activity (e.g., Nauhaus et al., 2002; Treude et al., 2003). In non-seep settings, such as oxygen minimum zone sediments, respiration of organic matter, including dissimilatory sulfate reduction, control oxygen concentrations, sulfide availability, and indirectly the habitability of the local environment for sulfur bacteria (e.g., Schulz et al., 2000).

Like the conspicuous sulfur-oxidizing $\gamma$-proteobacteria described above, the neutrophilic Fe(II)-oxidizing bacteria are also known to form mats (Fig. 2f) and mediate authigenic mineral precipitation (e.g., Emerson and Moyer, 2002; 
Edwards et al., 2004; Toner et al., 2009). Furthermore, considerable evidence exists for the preservation of Fe-oxidizing bacteria in ancient rocks (Trewin and Knoll, 1999; Little et al., 2004; Schmidt and Schäfer, 2005; Cavalazzi, 2007). Finally, chemosynthetic organisms from other groups such as the Aquificales and the $\varepsilon$-proteobacteria are known to form mats (Fenchel, 1994; Reysenbach et al., 2002; Engel et al., 2003; Omoregie et al., 2008). The possibility that these organisms also contributed to the ancient microbialite record should not be overlooked.

\section{Chemoorganotrophs}

Nonphotosynthetic mats are not restricted to those microbes that derive their energy from inorganic sources. Heterotrophic bacteria are ubiquitous in marine sediments but generally do not form microbial mats at the sediment/ water interface because of metazoan grazing, bioturbation, nutrient limitations, and, in the case of obligate anaerobes, the presence of oxygen. In the Black Sea, the co-occurrence of methane seeps, sulfate, and anoxic bottom waters allows for the growth of extensive microbial mat communities associated with the anaerobic oxidation of methane (AOM) (Peckmann et al., 2001; Thiel et al., 2001; Michaelis et al., 2002) (Fig. 3a, 3b). These microbial "reefs" can grow up to $4 \mathrm{~m}$ high and $1 \mathrm{~m}$ in diameter and are partially lithified with calcium carbonate. The observance of biologically similar, but presently unlithified, mats at depths of up to $10 \mathrm{~cm}$ in adjacent sediments suggests that these reefs may begin forming in the subsurface and that the eventual precipitation of a calcareous core leads to their growth into the overlying water column (Treude et al., 2005). Flat-lying, layered AOM mats that contain abundant extracellular polymeric substances were also recently discovered at the sediment/water interface in the Black Sea, which further extends the known mat expressions of AOM (Krüger et al., 2008). The importance of methane as a carbon source for the Black Sea mats is reflected in average $\delta^{13} \mathrm{C}$ values of $-67.1 \%$ for mat biomass (Michaelis et al., 2002; Treude et al., 2007).

Thus far, the expression of AOM-driven biomass as a mat is known only from the Black Sea. Although AOM communities in open marine environments are not known to form mats at the sediment/water interface, their metabolic activities result in the precipitation of expansive authigenic carbonates at the seafloor (Fig. 3c, 3d) (e.g., Lein, 2004). The dominant form of anaerobic oxidation of methane in marine environments involves a metabolic association between sulfate-reducing proteobacteria and uncultured archaea (ANME 1, 2, and 3) (Fig. 1d) (Hinrichs et al., 1999; Boetius et al., 2000; Orphan et al., 2001; Knittel et al., 2005; Niemann et al., 2006). The net AOM reaction with sulfate,

$$
\mathrm{CH}_{4}+\mathrm{SO}_{4}^{2-} \rightarrow \mathrm{HCO}_{3}^{-}+\mathrm{HS}^{-}+\mathrm{H}_{2} \mathrm{O}
$$

results in the production of bicarbonate (Reeburgh, 1976; Baker and Burns, 1985; Lein, 2004). This increase in carbonate alkalinity is thought to foster the precipitation of carbonate chimneys, nodules, and pavements that can cover hundreds of meters of seafloor at seep sites (discussed further below) (e.g., Ritger et al., 1987; Lein, 2004; Peckmann and Goedert, 2005). The close association between AOM consortia and mats of sulfur-oxidizing bacteria at localities like Hydrate Ridge, the Eel River Basin, and the Gulf of Mexico, for example, Joye et al. (2004), provides the potential for matforming organisms to be preserved in seep carbonates (Peckmann et al., 2004; Knittel et al., 2005; Teichert et al., 2005). Figure 4a shows wavy laminae that may represent the lithification of mat biomass within a recent seep carbonate sample from the Eel River methane seep locality. This same sample preserves abundant small filaments that could represent a seep-associated microbial mat (Fig. 4b). Other fabrics associated with seep carbonates include clotted fabrics, botryoidal cements, stromatolitic laminae, peloids, breccia, oncoids, and coated grains (Ritger et al., 1987; Matsumoto, 1990; Greinert et al., 2002; Shapiro, 2004; Aiello, 2005; Jenkins et al., 2008).

\section{"Morphologically convergent" structures at seeps}

Certain structures, such as stromatolites and oncoids, are most commonly thought to occur in shallow water carbonate-dominated environments in association with phototrophic organisms, but analogies can be found in deep seep environments formed in the absence of light. For example, stromatolitic fabrics have been observed under cathodoluminescence in recent seep carbonates from water depths $>4000$ meters, which demonstrates a convergence of morphological features derived from disparate processes (Greinert et al., 2002) (Fig. 4c). The alternating laminations in these carbonates incorporate varying amounts of Fe and Mn

FIG. 2. Chemotrophic microbial mats in the environment. (a) Seafloor view of Beggiatoa-dominated mat exhibiting a wrinkled texture from the Costa Rica margin oxygen minimum zone. Scale bar $=\sim 40 \mathrm{~cm}$. (b) Gulf of Mexico mat dominated by filamentous Beggiatoa (f) and globular Thiomargarita (t) contains cohesive mat-bound sediment chips (c) similar to those observed in ancient sediments. Scale bar $=1 \mathrm{~cm}$. Images of mats in the Gulf of Mexico were conducted using the R/V Seward Johnson in July 2001 and July 2002. Gulf of Mexico seafloor images were obtained using a submersible mounted Nikon CoolPix camera contained within a pressure housing, positioned by the robot arm of the submersible, and operated by a scientist inside the submersible. (c) Close-up seafloor view of mixed white and orange Beggiatoa mats from the Gulf of Mexico showing geometric patterns. Inset: sulfide-rich reducing sediments are home to mats with complex architecture and composition. Scale bar for primary image $=150 \mathrm{~cm}$. Scale bar for inset $=75 \mathrm{~cm}$. (d) Seafloor view of a predominantly orange Beggiatoa mat. Scale bar $=150 \mathrm{~cm}$. Inset: magnified view of microbial mat. Note the complex architecture. Scale bar for inset $=0.5 \mathrm{~cm}$. (e) Mats associated with hydrocarbon seeps from the Gulf of Mexico exhibit convolute patterns with elongate ridges (r) similar to some ancient wrinkle structures. These mats are primarily composed of large sulfur-oxidizing bacteria, such as Beggiatoa and Thiomargarita. Scale bar $=10 \mathrm{~cm}$. (f) Mats of Fe-oxidizing bacteria encrusted by ferric oxides are associated with small chimney structures at the hydrothermally active Loihi seamount. Scale bar $=45 \mathrm{~cm}$. Photo courtesy of Woods Hole Oceanographic Institution, taken during cruise MGLN10MV, Jason Dive J2-242 (2006) as part of the Iron Microbiology Observatory project. Scale bars are approximate. 

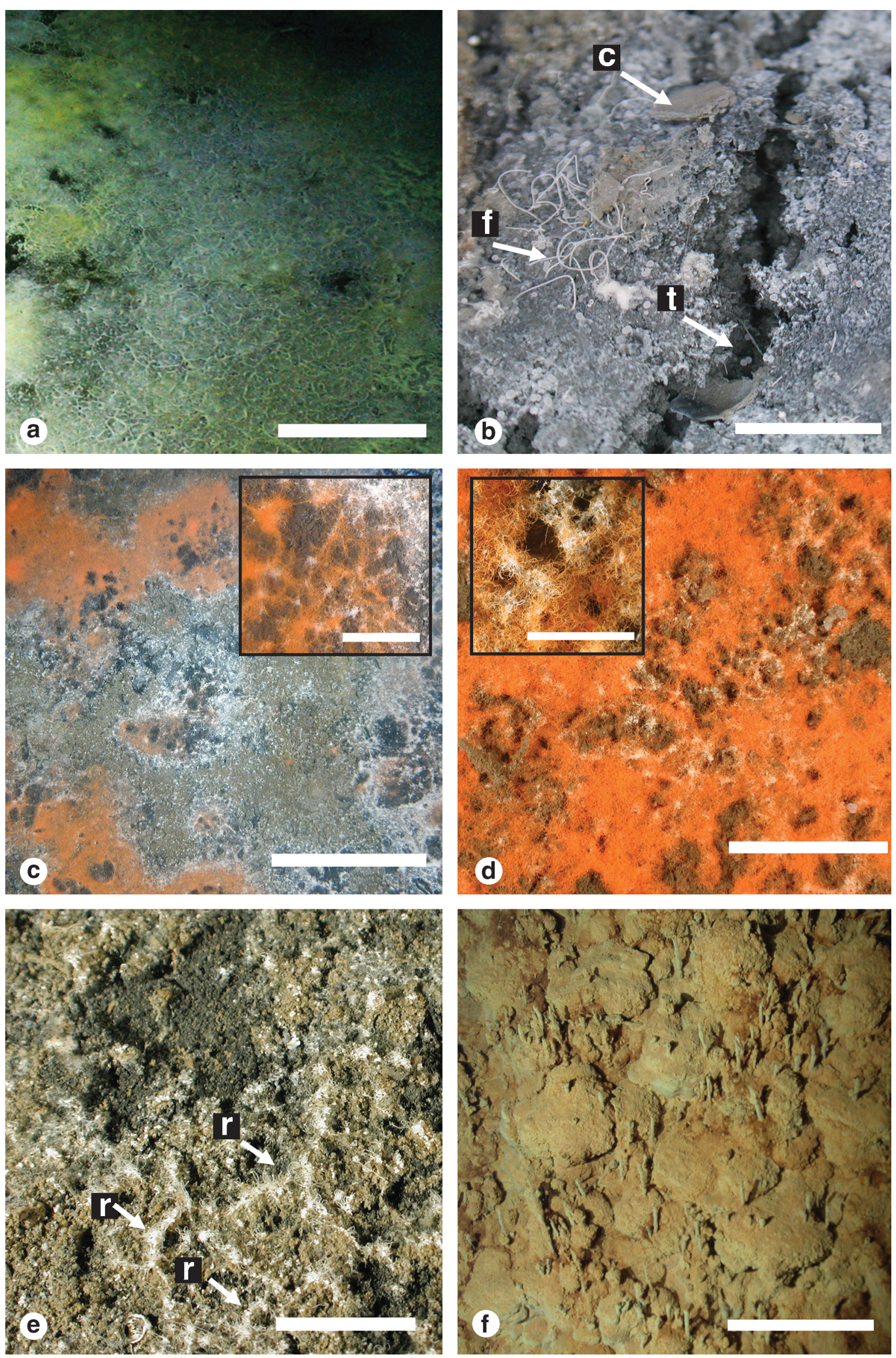

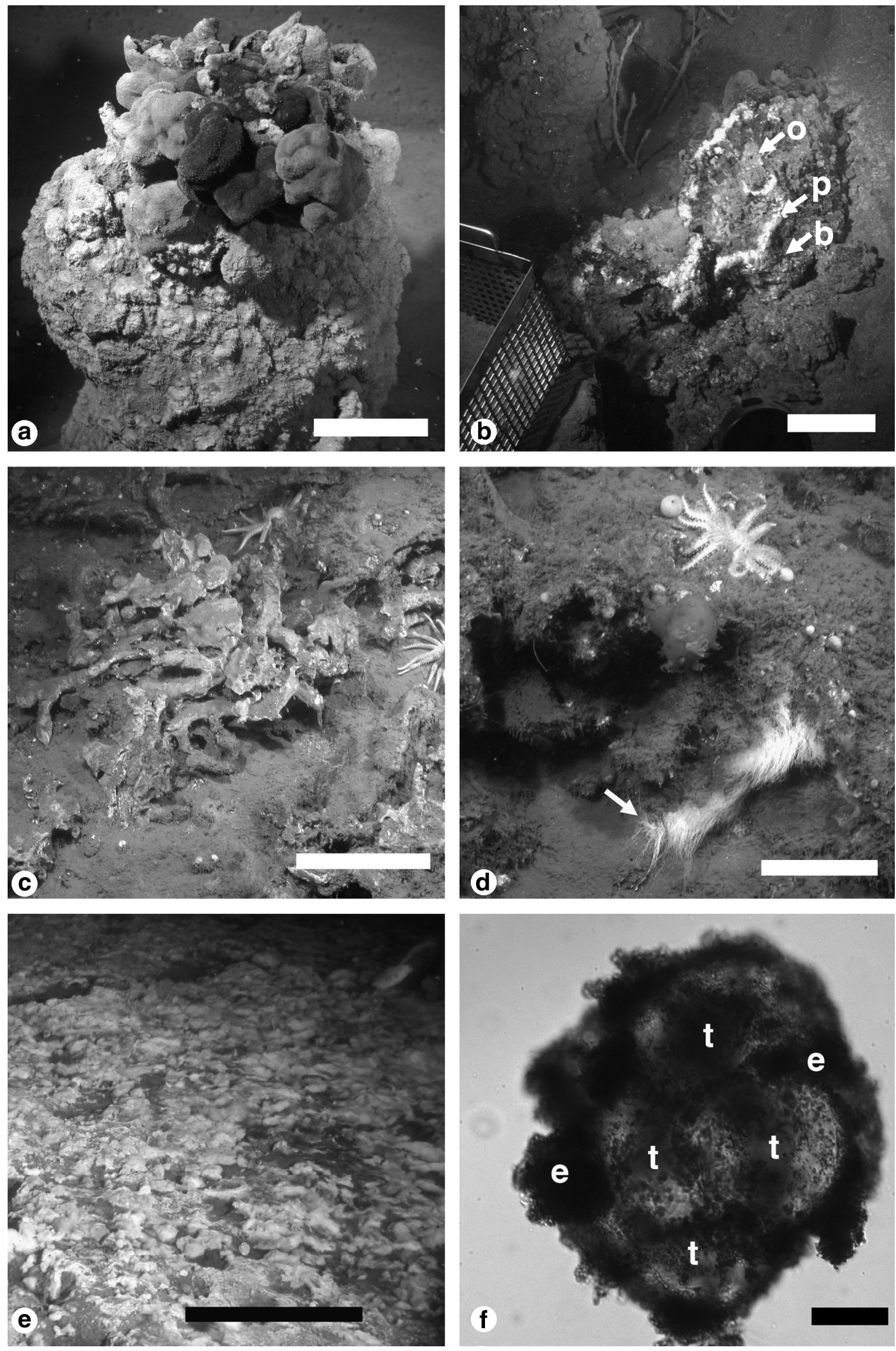
into the carbonate lattice, perhaps driven by frequent shifts in redox conditions (Greinert et al., 2002). Chemical gradients or changing redox conditions may also be responsible for the direction of the accretionary growth of these structures, which is oriented downward into the sediments, rather than upward into the water column (Greinert et al., 2002).

Coated grains that resemble ooids or oncoids are another morphologically convergent lithology found in modern seep deposits (Jenkins et al., 2008). The grains may have formed by agitation and rolling under seep fluid flow conditions; or, alternatively, the coating may have occurred within a microbial mat (Jenkins et al., 2008).

Clotted fabrics, peloids, dumbbell-shaped aggregates of carbonate crystals, and other non-detrital micrite matrices are other common features of modern and ancient seep carbonates (Larkin et al., 1994; Peckmann et al., 2002; Shapiro, 2004), and these features are often thought to have microbial origins (Chafetz, 1986). Microbially produced exopolymeric substances were shown to have a direct influence on carbonate morphology, producing shapes that may be diagnostic for ancient microbial activity (Braissant et al., 2003; Bontognali et al., 2008). In most cases, however, the existence of a direct link between AOM biomass and these lithologies is not well established.

\section{Chemotrophs in the Ancient Rock Record}

\section{Preservation in phosphorites}

More than two decades ago, the presence of sulfideoxidizing bacteria, such as Beggiatoa, in modern, oxygenpoor, phosphogenic settings led Williams and Reimers (1983) to interpret phosphatized filaments from the Miocene Monterey Formation as fossilized sulfur bacteria and propose that these organisms were involved in microbially mediated phosphogenesis (Reimers et al., 1990; Nathan et al., 1993; Krajewski et al., 1994). Very large bundles of filaments that resemble Thioploca shown in this study were recovered from Monterey phosphorites (Fig. 4d, 4e; Corsetti, Greene, and Bailey, unpublished data), which bolstered the evidence for sulfur bacteria in the Monterey Formation. Subsequent to Williams and Reimer's initial suggestion, Thiomargarita was discovered living in sediments beneath the Benguela upwelling zone-sediments in which modern phosphorites are forming (Schulz et al., 1999). In laboratory experiments, Thiomargarita was shown to mediate pore-water phosphorous concentrations actively through polyphosphate storage and metabolism (Schulz and Schulz, 2005). While polyphosphate utilization is ubiquitous, only a limited number of microbes store large amounts as intracellular inclusions (Kornberg, 1995). The release of orthophosphate into discrete pore-water horizons by Thiomargarita was calculated by
Schulz and Schulz (2005) to be sufficient to explain porewater P enrichment and apatite precipitation in Benguela sediments. Additionally, the precipitation of phosphatic minerals may also be catalyzed by a reduction in pore-water $\mathrm{pH}$ resulting from the oxidation of $\mathrm{H}_{2} \mathrm{~S}$ (Krajewski et al., 1994). These biological processes generate pore-water conditions that are conducive to the abiotic precipitation of phosphatic minerals (Krajewski et al., 1994; Schulz and Schulz, 2005):

$$
10 \mathrm{Ca}^{2+}+6\left(\mathrm{P}_{i}+\mathrm{CO}_{3}^{2-}\right)+2-3 \mathrm{~F}^{-} \rightarrow \mathrm{Ca}_{10}\left(\mathrm{PO}_{4}, \mathrm{CO}_{3}^{2-}\right)_{6} \mathrm{~F}_{2-3}
$$

Phosphatic precursors to apatite are thought to commonly nucleate on cells, which leads to the phosphatization of microbes, and phosphatized cells are common in Phanerozoic phosphorites (Soudry and Champetier, 1983; Krajewski et al., 1994). Some phosphatized globular structures in Neoproterozoic phosphorites may represent Thiomargarita-like bacteria that were preserved in sediments where apatite was actively precipitating from the massive release of phosphate into sediment pore waters (Bailey et al., 2007). Phosphatic stromatolites could also potentially be the product of phosphogenesis driven by chemotroph polyphosphate metabolism (Krajewski et al., 2000; Chacón and Martín-Chivelet, 2008). While Thiomargarita is currently the only sulfideoxidizing bacterium that has been studied with respect to phosphogenesis, recent whole-genome sequencing has revealed the genes necessary for polyphosphate metabolism in Beggiatoa (Mußmann et al., 2007). Additionally, the formation of modern phosphorites correlates closely with the habitats of other sulfur-oxidizing bacteria such as Thioploca (Baturin and Bezrukov, 1976).

\section{Preservation in siliciclastic sediments}

The preservation of filamentous sulfur-oxidizing bacteria in the rock record is not limited to phosphorites. During metabolism, and when hydrogen sulfide is readily available, sulfur bacteria commonly produce elemental sulfur or other sulfur-bearing intermediates that are either stored as intracellular sulfur globules for later use (Nelson and Castenholz, 1981; Schmidt et al., 1987) or excreted from the cell as globules or filaments (Taylor et al., 1999; Wirsen et al., 2002). For example, filamentous polysulfide excretion is associated with an e-proteobacterium (Taylor et al., 1999; Wirsen et al., 2002). In some cases, these extracellular sulfur deposits can create large mat-like structures composed, not of biomass, but of hydrophilic sulfur filaments (Taylor et al., 1999). Massive sedimentary sulfur deposits intercalated with siliciclastic sediments such as the Pleistocene Be'eri sulfur deposits of Israel may have resulted from bacterial sulfur fixation (Nissenbaum and

FIG. 3. Lithologies associated with modern chemotrophs. (a) Microbial mat edifice from the Black Sea composed of partially lithified mat composed of bacteria and archaea that oxidize methane anaerobically. Photo contributed by Bo Barker Jørgensen. Scale bar $=\sim 10 \mathrm{~cm}$. (b) Broken microbial carbonate edifice showing black (b), pink (p), and orange (o) mat biomass and methane seep bubbles that flow through internal channels in the mat. Photo contributed by Bo Barker Jørgensen. Scale bar $=\sim 20 \mathrm{~cm}$. (c) Contorted methane seep carbonate in outcrop. Scale bar $=\sim 40 \mathrm{~cm}$. (d) Filamentous Thiothrix mats (arrow) in the Eel River Basin frequently cover consolidated sediment and hardground substrates—such as this partially buried seep carbonate outcrop. Scale bar $=\sim 20 \mathrm{~cm}$. Photo taken in collaboration with Chris House. (e) Elemental sulfur precipitate atop highly reducing sediments from the Gulf of Mexico. Scale bar $=200 \mathrm{~cm}$. (f) Like cyanobacteria, Thiomargarita cells (t) are often surrounded by extracellular polymeric substances (e) that can trap and bind sediment grains. 

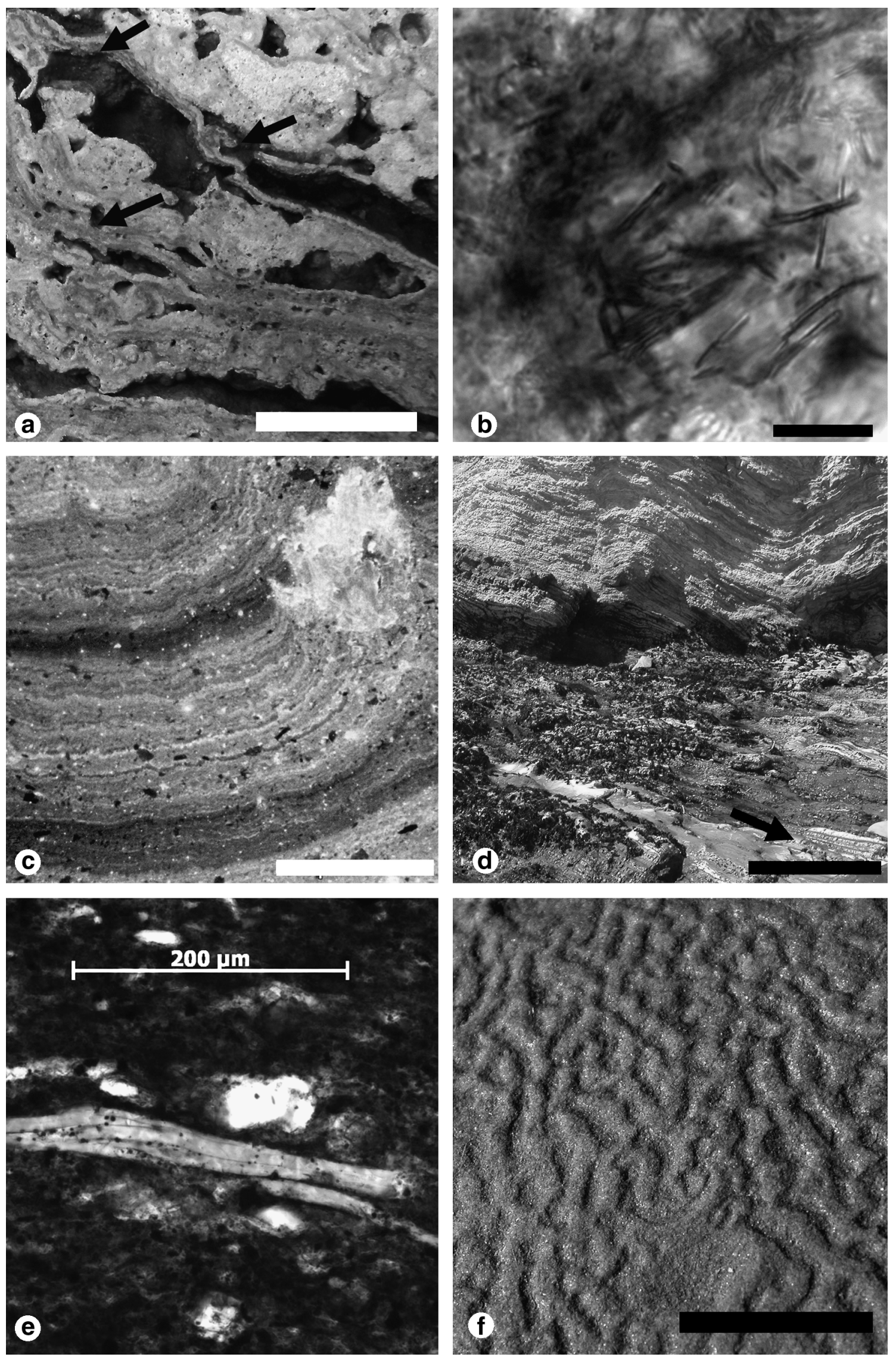
Kaplan, 1966; Druckman et al., 1994; Burhan et al., 2002). The origins of similar massive elemental sulfur deposits not associated with mat biomass in highly sulfidic sediments from the Gulf of Mexico remain unclear (Fig. 3e) but may be the result of abiogenic chemical reactions.

Convolute patterns on bedding plane surfaces in ancient siliciclastic rocks (e.g., wrinkle structures, Kinneyia, "elephant skin structures") and other indicators of sediment stabilization (e.g., sand chips, wavy laminae) are thought to result from the trapping and binding of sediment grains by extracellular polymeric substances produced by cyanobacteria (Hagadorn and Bottjer, 1997, 1999; Gehling, 1999; Noffke et al., 2002, 2003; Schieber et al., 2007; Noffke, 2008). These interpretations are based in large part on the observed formation of microbial-induced sedimentary structures in modern sediments stabilized by cyanobacterial mats (Hagadorn and Bottjer, 1997, 1999; Gerdes et al., 2000). While a cyanobacterial interpretation may be valid for a given putative microbialite occurrence, mats of sulfide-oxidizing bacteria can also stabilize sediment, and their chemotactic aggregation can result in elongate tufts, as well as crenulated, contorted, and geometric patterns similar to those seen in ancient wrinkle structures (e.g., Fig. 1 and Fig 4f; Thar and Kühl, 2002). Beggiatoa mat geometry, for example, can be complex and dynamic. Mat morphology is highly dependent on chemical gradients, with low oxygen resulting in the protrusion of tufts into the water column, while a phobic response to high oxygen levels, such as those that accompany higher flow velocity conditions, lead to a more cohesive mat that hugs the sediment (Moeller et al., 1985). While some marine sulfur bacterial mats are flocculent and easily disturbed, others are extremely cohesive, and Beggiatoa mats are known to withstand marine current velocities of $28 \mathrm{~cm} / \mathrm{s}$ (Soutar and Crill, 1977; Grant, 1991). Thiothrix filaments commonly attach to a variety of organic and inorganic surfaces to maintain their position in streams and currents (Fig. 3d), while Thiomargarita cells and cell clusters are often found surrounded by extracellular polymeric substances that bind sediment grains (Fig. 3f).

Unlike extant mat-stabilized siliciclastic sediments, some ancient wrinkle structures occur in subtidal, rather than peritidal, environments, and the preservation of Ediacaran fauna on mat-stabilized sediments generally occurred in deepwater depositional environments (Gehling, 1999). It is likely that deepwater mats were composed of chemotrophic organisms that thrived beneath the photic zone. Depositional environment has been used by other workers to identify probable remains of chemotrophs in ancient rocks. For example, thin, organic-rich wavy laminations from shales deposited in subtidal settings in the Miocene Monterey For- mation were interpreted by Williams (1984) to represent the remains of Beggiatoa-like mats based, in part, on the deepwater depositional environment (Williams, 1984). It should be noted that sulfur-oxidizing bacterial mats can form in water depths $<10 \mathrm{~cm}$ and can often co-occur with photosynthetic mats (e.g., Scotten and Stokes, 1962; Pitts et al., 1972; GarciaPichel et al., 1994; Fenchel and Bernard, 1995), so the possibility that chemotrophs existed in a particular depositional setting should not be excluded from consideration based on water depth. Similarly, fossil assemblages that include metazoans, eukaryotic algae, etc. are not incompatible with the preservation of chemotrophic mats. Thiomargarita thrives in diatomaceous oozes off the coast of Namibia in sediments that are made sulfidic by the anaerobic respiration of phytoplankton biomass derived from the overlying water column (Schulz et al., 1999). Eukaryotes and chemotrophs also cohabitate in life, as sulfide-tolerant invertebrates are known to live in close proximity to Beggiatoa mats (Hovland and Judd, 1988; Sibuet et al., 1988; Van Dover et al., 2002; Sommer et al., 2003). Wrinkle structures that occur in association with distinctive invertebrate assemblages, appear to preclude vertical bioturbation, or preserve abundant pyrite may indeed represent ancient thiobiotic or sulfide-tolerant ecosystems (Bailey et al., 2006). However, indicators of sulfidic conditions in mats do not exclude the presence of cyanobacteria, as cyanobacteria-dominated mats commonly include high levels of sulfide produced through dissimilatory sulfate reduction (Visscher et al., 2000).

\section{Preservation in carbonates}

Sulfur bacteria are also apparently preserved in carbonate rocks, in addition to phosphorites, and siliciclastic sediments. Complete sulfide oxidation to sulfate with oxygen is an acidproducing reaction

$$
\mathrm{HS}^{-}+2 \mathrm{O}_{2} \rightarrow \mathrm{SO}_{4}^{2-}+\mathrm{H}^{+}
$$

and yet at methane seeps carbonate precipitation driven by AOM does not appear to be inhibited by Beggiatoa and Thiothrix mats that grow prolifically at these sites. One possible explanation is that the protons produced by sulfide oxidation are spatially or temporally decoupled from the alkalinity generated by AOM. Beggiatoa mats are sometimes known to act as a barrier for hydrocarbon flow in sediments, which leads to the accumulation of methane with a concomitant increase in the amount of methane oxidation occurring beneath mats (Orphan et al., 2004). In other cases, gas appears to vent through conduits in the mat (Joye, unpublished observation) or by channels in the mat architecture that purportedly enhance fluid flow and $\mathrm{O}_{2}$ availability to

\footnotetext{
FIG. 4. (a) Evidence of chemotrophic mats in recent and ancient sediments. Contorted laminae (indicated by arrows) in recent seep carbonate sample recovered using the ROV Tiburon from the Eel River Basin as previously described in Orphan et al. (2004). Scale bar $=1 \mathrm{~cm}$. (b) Fossilized filaments preserved in seep carbonate pictured in (a). Scale bar $=100 \mu \mathrm{m}$. (c) Stromatolitic textures visible under cathodoluminescence preserved in seep carbonates from a water depth of 4085 meters (reproduced from Greinert et al., 2002). Scale bar $=600 \mu \mathrm{m}$. (d) Phosphorites (arrow) overlain by diatomites from the Miocene Monterey Formation at Shell Beach, California, preserve filaments in (f). Scale bar $=\sim 80 \mathrm{~cm}$. (e) Bundle of large phosphatized filaments from the Monterey Formation resembles Thioploca. Image taken in collaboration with Sarah Greene. (f) Wrinkle structures are thought to have formed as a result of stabilization of sediments by microbial mats that potentially could have been composed of either phototrophs or chemotrophs. This specimen comes from Lower Cambrian sediments of the Harkless Formation, Inyo County, California. Scale bar $=1 \mathrm{~cm}$.
} 
the mat inhabitants (Fenchel and Glud, 1998). Another possibility is that sulfide oxidation that occurs at seeps might be largely driven by reduction of $\mathrm{NO}_{3}^{-}$(Sayama, 2001) as opposed to $\mathrm{O}_{2}$, an acid-consuming reaction,

$$
\mathrm{HS}^{-}+\mathrm{NO}_{3}^{-}+\mathrm{H}^{+}+\mathrm{H}_{2} \mathrm{O} \rightarrow \mathrm{SO}_{4}^{2-}+\mathrm{NH}_{4}^{+}
$$

that is a common mode of respiration for marine sulfur bacteria. A pH minimum zone is often associated with the position of Beggiatoa in the sediments, and this has been shown to lead to carbonate dissolution (Cai et al., 2006). In general, porewater carbonate chemistry at methane seep sites displays a high degree of spatial variability (Cai et al., 2006), and most carbonate precipitation likely occurs at depth in the sediments where dissolved inorganic carbon concentrations are much higher than they are at the sediment/water interface. Regardless of the biogeochemical explanation, filamentous sulfur-oxidizing mats co-occur with authigenic carbonate precipitation at many seep sites, which might explain why large filaments are preserved in both recent (Fig. 4a) and ancient seep carbonates. For example, filaments consistent with Beggiatoa are preserved in methane seep-derived limestone from Tertiary rocks in Italy (Cavagna et al., 1999; Peckmann et al., 2004; Barbieri and Cavalazzi, 2005) and the Oligocene of Poland (Bojanowski, 2007). Also, Cretaceous seep carbonates from Tepee Buttes, Colorado, exhibit thrombolitic and stromatolitic textures at the mesoscale, as well as fossilized microbial cells (Shapiro, 2004).

Seep carbonates are relatively abundant in the Phanerozoic rock record (see review by Campbell, 2006). These carbonate deposits within largely siliciclastic successions show ${ }^{13} \mathrm{C}$ depletion typical of modern seep carbonates (Campbell and Bottjer, 1995; Goedert et al., 2003; Gill et al., 2005). Distinctive macrofaunal assemblages are thought to represent communities of seep-adapted invertebrates, such as endosymbiont-hosting bivalves and tube worms (Taviani, 1994; Squires, 1995; Goedert and Kaler, 1996). AOM-diagnostic lipid biomarkers such as crocetane and PMI $(2,6,10,15,19$ pentamethylicosane) are known from seep carbonate limestones as old as the Pennsylvanian ( $c a .300$ million years ago) (Birgel et al., 2006, 2008). Potentially, carbonates generated under reducing conditions may preserve fossilized morphologically distinctive AOM aggregates. Vermiform textures in recent seep carbonates from the Gulf of Mexico have been interpreted as calcified AOM biomass (Chen et al., 2007). Also, pyrite framboids from recent seep carbonates superficially resemble AOM aggregates (Chen et al., 2007), and a genetic association has been suggested (Popa et al., 2004). A link between framboids and AOM consortia, however, is yet to be firmly established. Filaments entombed in aragonite in Oligocene seep carbonates were interpreted by Peckmann et al. (2002) as possible filaments of ANME archaea similar to those seen in modern seep environments (Orphan et al., 2002). However, the diameters of extant ANME filaments are markedly smaller $(c a .1 \mu \mathrm{m})($ e.g., Fig. 2I in Knittel et al., 2005). Alternatively, these filaments could represent sulfide-oxidizing $\gamma$ - or $\varepsilon$-proteobacteria.

\section{The case for filamentous microfossils: cyanobacteria or not?}

The preservation of filaments or filament-like microstructures in ancient rocks is often interpreted as the remnants of cyanobacteria based on morphological considerations (Butterfield and Rainbird, 1998). Though there are substantial morphological similarities between sulfur-oxidizing bacteria and cyanobacteria, Beggiatoa is unlikely to be differentiated from a filamentous cyanobacterium like Oscillatoria spp. by using size and shape of body fossils alone. Similarly, large coccoidal chemotrophic bacteria, such as Thiovulum, Achromatium, and Ovobacter, commonly exceed $5 \mu \mathrm{m}$ in diameter (Thar and Fenchel, 2005), which makes them alternative candidates for the origin of large coccoidal fossils that are often interpreted as cyanobacteria. There are a number of features that might be used to distinguish between representatives of the two clades, though these may only be informative under certain circumstances (summarized in Table 1). First, the morphologies and division patterns of known sulfur-oxidizing bacteria do not encompass the entire

Table 1. Potential Indicators of MAT-Forming Microbes

\begin{tabular}{|c|c|c|c|}
\hline & Cyanobacteria & $\begin{array}{c}\text { Sulfur } \\
\text { bacteria }\end{array}$ & $\begin{array}{c}\text { AOM } \\
\text { consortia }\end{array}$ \\
\hline Stromatolites & $+{ }^{1}$ & $-/+$ & $+^{2}$ \\
\hline Elemental sulfur deposits & - & $+^{3}$ & - \\
\hline Phosphorites & $?$ & $+^{4}$ & - \\
\hline Wrinkle structures & $+^{5}$ & $+{ }^{6}$ & - \\
\hline Large filaments & $+^{7}$ & $++^{8}$ & - \\
\hline${ }^{13} \mathrm{C}$-depleted carbonates & - & $-/+$ & $+{ }^{9}$ \\
\hline Distinctive lipid biomarkers & $+{ }^{10}$ & $?^{11}$ & $+{ }^{12}$ \\
\hline Pyrite framboids & $+{ }^{13}$ & $+{ }^{14}$ & $+{ }^{15}$ \\
\hline Porous carbonates & $+{ }^{16}$ & $+{ }^{17}$ & $+{ }^{18}$ \\
\hline Peloids and ooids & $+{ }^{16}$ & $?$ & $+{ }^{19}$ \\
\hline Peritidal settings & $+{ }^{20}$ & $+{ }^{8}$ & $?$ \\
\hline Subtidal settings & $+{ }^{20}$ & $+^{8}$ & $+{ }^{21}$ \\
\hline Bathyal settings & - & $+^{8}$ & $+{ }^{22}$ \\
\hline
\end{tabular}

? indicates that a specific group of organisms has not specifically been reported and associated with a given feature but that current evidence cannot reasonably preclude such an association.

$-/+$ indicates mats of sulfur bacteria are not associated with that indicator unless living in association with AOM consortia.

Representative citations:

${ }^{1}$ Logan, 1961; Visscher et al., 2000.

${ }^{2}$ Greinert et al., 2002.

${ }^{3}$ Taylor et al., 1999.

${ }^{4}$ e.g., Williams and Reimers, 1983; Nathan et al., 1993; Schulz et al., 1999

${ }^{5}$ Hagadorn and Bottjer, 1997, 1999.

${ }^{6}$ Bailey et al., 2006, and Fig. 2 this article.

${ }^{7}$ Knoll, 2008.

${ }^{8}$ Teske and Nelson, 2006

${ }^{9}$ Stakes et al., 1999.

${ }^{10}$ Summons et al., 1999.

${ }^{11}$ Arning et al., 2008.

${ }^{12}$ Hinrichs et al., 1999, 2000.

${ }^{13}$ Stal, 2000.

${ }^{14}$ Larkin et al., 1994.

${ }^{15}$ van Dongen et al., 2007.

${ }^{16}$ Monty, 1976.

${ }^{17}$ Teichert et al., 2005.

${ }^{18}$ Michaelis et al., 2002; Teichert et al., 2005.

${ }^{19}$ Jenkins et al., 2008.

${ }^{20}$ Cohen and Gurevitz, 2006.

${ }^{21}$ Campbell, 2006.

${ }^{22}$ Hinrichs et al., 1999; Boetius et al., 2000; Orphan et al., 2001; Knittel et al., 2005; Niemann et al., 2006. 
FIG. 5. Tectonic processes play an important role in forcing the expulsion of reduced fluids from depth and providing conduits for fluid escape. Beggiatoa mats from the Eel River Basin aligned along linear seep fluid conduits. Scale bar $=\sim 20 \mathrm{~cm}$.

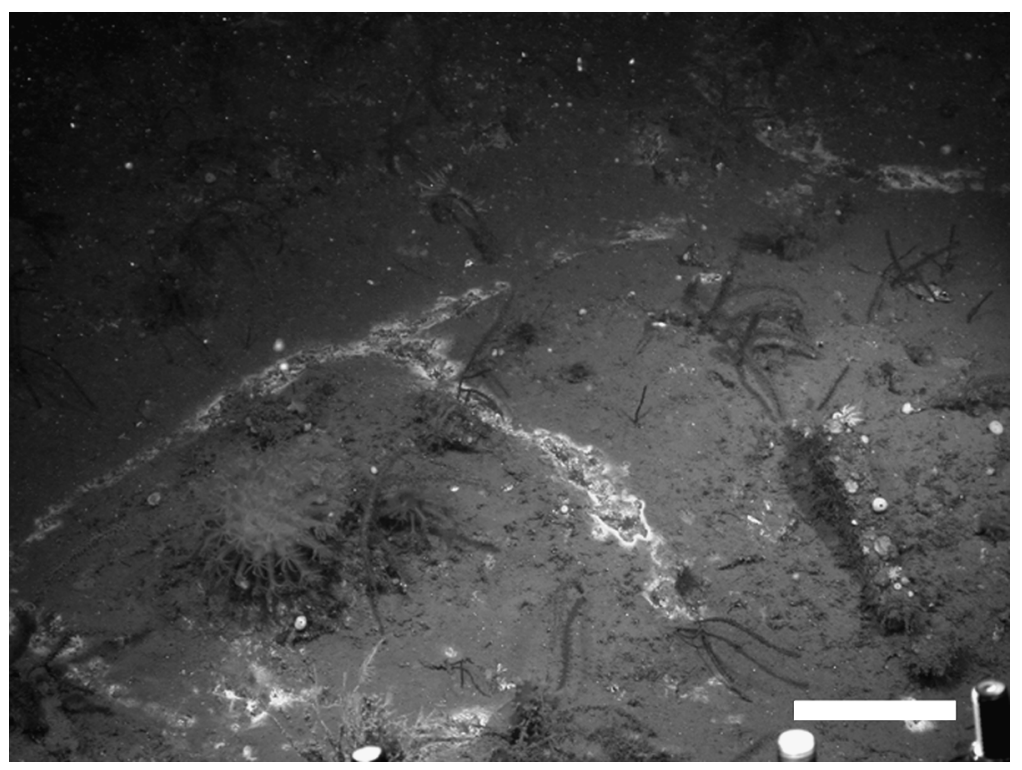

range of shapes and life cycles observed in ancient microfossils and the extant cyanobacteria they are interpreted to represent (see review by Knoll, 2008). Likewise, some sulfuroxidizing bacteria have their own distinctive sizes and morphologies. Second, many sulfur bacterial cells frequently contain abundant sulfur globules, which potentially could be preserved as sulfur-containing minerals associated with the filamentous body fossils. Third, certain lipid biomarkers can be preserved in ancient rocks, and these might be used to infer the phylogeny of associated or coeval microfossils. For example, 2-methylhopanes are thought to be indicative of phototrophic bacteria (Summons et al., 1999). Lipid biomarker profiles from modern phosphogenic settings include mono-O-alkyl glycerol ethers. These lipids are apparently synthesized by sulfate-reducing bacteria that are commonly associated with sulfur-oxidizing bacteria (Arning et al., 2008). A direct link to sulfur-oxidizing bacteria is not yet clear, and these associations in modern phosphogenic settings have yet to be extended to the analysis of geolipids in ancient rocks. One potential complication of using a lipid biomarker approach to identify the inhabitants of ancient mat ecosystems is the cohabitation of diverse clades in many mats (Franks and Stolz, 2008). For example, Ding and Valentine (2008) found that aerobic methanotrophs contribute up to $46 \%$ of the fatty acids to organic extracts from mats associated with hydrocarbon seeps that visually appear to be dominated by sulfur-oxidizing bacteria.

\section{Evolution of chemotrophic mats}

The timing of the evolution of various mat-forming chemotrophic communities remains poorly resolved. One limitation to the antiquity of sulfide-oxidizing mat communities is their requirement for microaerophilic levels of oxygen or $\mathrm{NO}_{3}^{-}$, a compound whose formation is dependent on oxygen. This requirement for oxygen, when considered alongside geochemical indicators of ocean oxygenation (Fike et al., 2006; Canfield et al., 2007), may constrain their occurrence in marine shelf settings to the Phanerozoic and Late Proterozoic. This timing is consistent with molecular clock estimates that place the divergence of the clade containing the conspicuous sulfur-oxidizing $\gamma$-proteobacteria during the Late Proterozoic (Canfield and Teske, 1996), though debate exists over the reliability of various molecular clock estimates (Hedges et al., 2006). Alternatively, isotopic evidence for sulfur disproportionation in the Mesoproterozoic may be related to the production of sulfur intermediates by chemotrophic sulfur bacteria (Johnston et al., 2005).

Anaerobes, such as the sulfate-reducing bacteria and archaea involved in the anaerobic oxidation of methane, have no requirement for $\mathrm{O}_{2}$, and anoxic marine conditions may have allowed AOM mats to grow at the sediment/water interface as they do in the modern Black Sea. The flourishing of AOM mats in a euxinic basin, such as the Black Sea, hints at a possible analogue to life in Proterozoic euxinic seas (Canfield, 1998) or restricted basins. Interestingly, no carbonates with ${ }^{13} \mathrm{C}$ depletions characteristic of seep carbonates are known from before the Neoproterozoic (Jiang et al., 2003). This paucity of Precambrian seep carbonates may be the result of non-actualistic geochemical conditions, such as low sulfate concentrations in the world's ocean, evolutionary processes, or simply a low preservation potential due to the frequent proximity of seafloor seep environments to subduction zones.

\section{Conclusions and Relevance to Astrobiology}

Abundant chemosynthetic microbes possess gliding motility, chemotaxis, large size, and the ability to secrete extracellular polymeric substances that can bind sediment. These characteristics make sulfide-oxidizing bacteria potential candidates for the formation of ancient organo-sedimentary structures that require the trapping and binding of sediment. Furthermore, sulfide-oxidizing bacteria and AOM-related organisms both form microbial mats that are associated with the precipitation of authigenic minerals. The common preservation of microbial body fossils in seep carbonates stands in contrast to other carbonate depositional systems in which early silicification is usually required to preserve cell structure (Knoll, 1985). We suggest that some ancient stromatolites 
and wrinkle structures may have formed in the presence of nonphotosynthetic communities. Lipid biomarkers, isotopic signatures, and sedimentological indicators of the local depositional environment may provide evidence that can be used to differentiate between those microbialites that formed in association with chemotrophs and those that formed in association with phototrophs; but, in the absence of such evidence, the possibility of chemotrophic involvement should not be ruled out. In cases where stromatolites, wrinkle structures, and other putative microbialites are thought to have formed in depositional environments that were below the photic zone, abiotic precipitation or mediation by chemosynthetic organisms is likely-though shallower depositional environments in no way preclude the potential for chemotrophic mat preservation. The mediation of phosphorite precipitation by sulfur-oxidizing communities in modern marine settings makes the association of sedimentary phosphorites with putative microbialites a potential indicator of chemosynthetic metabolism.

The occurrence and distribution of terrestrial chemotrophic microbial mat ecosystems may also hold important lessons for detection of life on other planets. The redox reactions performed by chemolithotrophs act as a bridge between biological and planetary/geological processes; but, in general, these organisms are exploiting natural interfaces between fluids of differential redox potential. For example, many chemosynthetic communities occur where tectonic processes inject reducing fluids, hydrocarbons, or both into sediment pore waters that contain oxidizing agents (e.g., $\mathrm{O}_{2}, \mathrm{NO}_{3}^{-}, \mathrm{SO}_{4}^{2-}$ ) (Fig. 5; Reilly et al., 1996). On Mars, evidence exists for water, oxidized chemical species such as sulfates (Bridges et al., 2001; Elwood Madden et al., 2004), and potential electron donors such as methane (Formisano et al., 2004). Tectonism or processes such as impact cratering that can drive hydrothermal processes on Mars or other planets (Kring and Abramov, 2005) may have led to fluid transport between reduced fluids and photochemically oxidized conditions near the planetary surface. It is perhaps at these natural interfaces and mixing zones that the search for extant or ancient nonphotosynthetic life is most likely to find success. One potential strategy for detecting ancient vents or seeps would be to look for the alteration of mineral assemblages or the presence of authigenic mineral deposits within host rock, either exposed at the surface or imaged remotely in the subsurface (Newsom et al., 2001; Shapiro, 2004).

A number of questions still remain about chemotrophic microbes and their potential for preservation in the rock record. For example, why are microbial body fossils commonly preserved in seep carbonates but not in carbonates from other depositional settings? Do AOM mats play a role in the precipitation of authigenic carbonates, beyond increasing carbonate alkalinity? Do phosphorites primarily result from the metabolic sequestration and subsequent release of phosphorous by sulfur-oxidizing bacteria? Answering these questions, and many others, will undoubtedly help us better understand the history of life on Earth and will aid in the search for life beyond our planet.

\section{Acknowledgments}

We thank Bo Barker Jørgensen, Heide Schulz-Vogt, Tina Treude, Jens Greinert, Chris House, Sarah Greene, Beth Or- cutt, Katrina Edwards, and Ian R. MacDonald for contributing or for helping to acquire images used in this manuscript. We also thank Heide Schulz-Vogt, Tomaso Bontognali, and four anonymous reviewers for helpful comments that greatly improved this manuscript. J.V.B. is supported by the Agouron Institute Geobiology Postdoctoral Fellowship Program (Grant \# AI-F-GB12.09.2). The Gulf of Mexico, Eel River Basin, and Costa Rica Margin images were obtained during projects funded by the U.S. National Science Foundation (OCE-0085549 to S.B.J.; MCB-0348492 to V.J.O.; and OCE-0825791 to V.J.O.). Images from the Loihi Seamount were taken during cruise MGLN10MV, Jason Dive J2242 (Woods Hole Oceanographic Institute) as part of the Iron Microbiology Observatory Project.

\section{Author Disclosure Statement}

No competing financial interests exist.

\section{Abbreviation}

AOM, anaerobic oxidation of methane.

\section{References}

Aiello, I. (2005) Fossil seep structures of the Monterey Bay region and tectonic/structural controls on fluid flow in an active transform margin. Palaeogeogr., Palaeoclimatol., Palaeoecol. 227:124-142.

Allwood, A.C., Walter, M.R., Kamber, B.S., Marshall, C.P., and Burch, I.W. (2006) Stromatolite reef from the Early Archaean era of Australia. Nature 441:714-718.

Arning, E.T., Birgel, D., Schulz-Vogt, H.N., Holmkvist, L., Jørgensen, B.B., Larsson, A., and Peckmann, J. (2008) Lipid biomarker patterns of phosphogenic sediments from upwelling regions. Geomicrobiol. J. 25:69-82.

Bailey, J.V., Corsetti, F.A., Bottjer, D.J., and Marenco, K.N. (2006) Microbially mediated environmental influences on Metazoan colonization of matground ecosystems: evidence from the Lower Cambrian Harkless Formation. Palaios 21:215-226.

Bailey, J.V., Joye, S.B., Kalanetra, K.M., Flood, B.E., and Corsetti, F.A. (2007) Evidence of giant sulphur bacteria in Neoproterozoic phosphorites. Nature 445:198-201.

Baker, P.A. and Burns, S.J. (1985) The occurrence and formation of dolomite in organic-rich continental margin sediments. Am. Assoc. Pet. Geol. Bull. 69:1917-1930.

Barbieri, R. and Cavalazzi, B. (2005) Microbial fabrics from Neogene cold seep carbonates, Northern Apeninne, Italy. $\mathrm{Pa}$ laeogeogr., Palaeoclimatol., Palaeoecol. 227:143-155.

Baturin, G.N. and Bezrukov, P.L. (1976) Phosphorite and phosphatic deposits on the ocean floor. In International Geological Congress, $25^{\text {th }}$ Session. Papers of Soviet Geologists: Paleontology and Marine Geology, Nauka, Moscow.

Birgel, D., Thiel, V., Hinrichs, K.U., Campbell, K.A., Reitner, J., Elvert, M., Farmer, J.D., and Peckmann, J. (2006) Lipid biomarker patterns of methane-seep microbialites from the Mesozoic convergent margin of California. Org. Geochem. 37:1289-1302.

Birgel, D., Himmler, T., Freiwald, A., and Peckmann, J. (2008) A new constraint on the antiquity of anaerobic oxidation of methane: Late Pennsylvanian seep limestones from southern Namibia. Geology 36:543-546.

Boetius, A., Ravenschlag, K., Schubert, C.J., Rickert, D., Widdel, F., Gieseke, A., Amann, R., Jørgensen, B.B., Witte, U., and Pfannkuche, O. (2000) A marine microbial consortium ap- 
parently mediating anaerobic oxidation of methane. Nature 407:623-626.

Bojanowski, M.J. (2007) Oligocene cold-seep carbonates from the Carpathians and their inferred relation to gas hydrates. Facies 53:347-360.

Bontognali, T.R.R., Vasconcelos, C., Warthmann, R.J., Dupraz, C., Bernasconi, S., and McKenzie, J.A. (2008) Microbes produce nanobacteria-like structures, avoiding cell entombment. Geology 36:663-666.

Braissant, O., Cailleau, G., Dupraz, C., and Verrecchia, E.P. (2003) Bacterially induced mineralization of calcium carbonate in terrestrial environments: the role of exopolysaccharides and amino acids. Journal of Sedimentary Research 73:485-490.

Bridges, J.C., Catling, D.C., Saxton, J.M., Swindle, T.D., Lyon, I.C., and Grady, M.M. (2001) Alteration assemblages in martian meteorites: implications for near-surface processes. Space Sci. Rev. 96:365-392.

Buick, R. (1984) Carbonaceous filaments from North Pole, Western Australia: are they fossil bacteria in Archean stromatolites? Precambrian Res. 24:157-172.

Burhan, R.Y.P., Trendel, J.M., Adam, P., Wehrung, P., Albrecht, P., and Nissenbaum, A. (2002) Fossil bacterial ecosystem at methane seeps. Origin of organic matter from Be'eri sulfur deposit, Israel. Geochim. Cosmochim. Acta 66:4085-4101.

Butterfield, N.J. and Rainbird, R.H. (1998) Diverse organicwalled fossils, including "possible dinoflagellates," from the early Neoproterozoic of arctic Canada. Geology 26:963-966.

Cai, W.-J., Chen, F., Powell, E.N., Walker, S.E., ParsonsHubbard, K.M., Staff, G.M., Wang, Y., Ashton-Alcox, K.A., Callender, W.R., and Brett, C.E. (2006) Preferential dissolution of carbonate shells driven by petroleum seep activity in the Gulf of Mexico. Earth Planet. Sci. Lett. 248:227-243.

Campbell, K.A. (2006) Hydrocarbon seep and hydrothermal vent paleoenvironments and paleontology: past developments and future research directions. Palaeogeogr., Palaeoclimatol., Palaeoecol. 232:362-407.

Campbell, K.A. and Bottjer, D.J. (1995) Brachiopods and chemosymbiotic bivalves in Phanerozoic hydrothermal vent and cold seep communities. Geology 23:321-324.

Canfield, D.E. (1998) A new model for Proterozoic ocean chemistry. Nature 396:450-453.

Canfield, D.E. and Teske, A. (1996) Late Proterozoic rise in atmospheric oxygen concentration inferred from phylogenetic and sulphur-isotope studies. Nature 382:127-132.

Canfield, D.E., Poulten, S.W., and Narbonne, G.M. (2007) LateNeoproterozoic deep-ocean oxygenation and the rise of animal life. Science 315:92-95.

Cavagna, S., Clari, P., and Martire, L. (1999) The role of bacteria in the formation of cold seep carbonates: geological evidence from Monferrato (Tertiary, NW Italy). Sediment. Geol. 126:253270.

Cavalazzi, B. (2007) Chemotrophic filamentous microfossils form the Hollard Mound (Devonian, Morocco) as investigated by focused ion beam. Astrobiology 7:402-415.

Chacón, B. and Martín-Chivelet, J. (2008) Stratigraphy of Palaeocene phosphate pelagic stromatolites (Prebetic Zone, SE Spain). Facies 54:361-376.

Chafetz, H.S. and Buczynski, C. (1992) Bacterially induced lithification of microbial mats. Palaios 7:277-293.

Chafetz, H.S. (1986) Marine peloids: a product of bacterially induced precipitation of calcite. Journal of Sedimentary Research 56:812-817.

Chen, D.F., Liu, Q., Zhang, Z., Cathles, L.M., III, and Roberts, H.H. (2007) Biogenic fabrics in seep carbonates from an active gas vent site in Green Canyon Block 238, Gulf of Mexico. Marine and Petroleum Geology 24:313-320.

Cohen, Y. and Gurevitz, M. (2006) The cyanobacteria-ecology, physiology and molecular genetics. In The Prokaryotes, edited by S. Falkow, E. Rosenberg, K.-H. Schleifer, E. Stackebrandt, and M. Dworkin, Springer-Verlag, New York, pp 1074-1098.

Dill, R.F., Shinn, E.A., Jones, A.T., Kelly, K., and Steinen, R.P. (1986) Giant subtidal stromatolites forming in normal salinity waters. Nature 324:55-58.

Ding, H. and Valentine, D.L. (2008) Methanotrophic bacteria occupy benthic microbial mats in shallow marine hydrocarbon seeps, Coal Oil Point, California. J. Geophys. Res. 113, doi:10.1029/2007JG000537.

Dravis, J.J. (1983) Hardened subtidal stromatolites, Bahamas. Science 219:385-386.

Druckman, Y., Weissbrod, T., and Aharon, P. (1994) Evidence for methane and hydrogen sulfide venting imprinted on a Quaternary eolianite from southern Israel. Geo-Marine Letters 14:170-176.

Dupraz, C. and Visscher, P.T. (2005) Microbial lithification in marine stromatolites and hypersaline mats. Trends Microbiol. 13:429-438.

Edwards, K.J., Bach, W., McCollom, T.M., and Rogers, D.R. (2004) Neutrophilic iron-oxidizing bacteria in the ocean: their habitats, diversity, and roles in mineral deposition, rock alteration, and biomass production in the deep-sea. Geomicrobiol. J. 21:393-404.

Elwood Madden, M.E., Bodnar, R.J., and Rimstidt, J.D. (2004) Jarosite as an indicator of water-limited chemical weathering on Mars. Nature 431:821-823.

Emerson, D. and Moyer, C.L. (2002) Neutrophilic Fe-oxidizing bacteria are abundant at the Loihi seamount hydrothermal vents and play a major role in Fe oxide deposition. Appl. Environ. Microbiol. 68:3085-3093.

Engel, A.S., Lee, N., Porter, M.L., Stern, L.A., Bennett, P.C., and Wagner, M. (2003) Filamentous "Epsilonproteobacteria" dominate microbial mats from sulfidic cave springs. Appl. Environ. Microbiol. 69:5503-5511.

Fenchel, T. (1994) Motility and chemosensory behavior of the sulfur bacterium Thiovulum majus. Microbiology 140:3109-3116.

Fenchel, T. and Bernard, C. (1995) Mats of colourless sulphur bacteria. I. Major microbial processes. Mar. Ecol. Prog. Ser. 128:161-170.

Fenchel, T. and Glud, R. (1998) Veil architecture in a sulphideoxidizing bacterium enhances countercurrent flux. Nature 394:367-369.

Fike, D.A., Grotzinger, J.P., Pratt, L.M., and Summons, R.E. (2006) Oxidation of the Ediacaran ocean. Nature 444:744-747.

Formisano, V., Atreya, S., Encrenaz, T., Ignatiev, N., and Giuranna, M. (2004) Detection of methane in the atmosphere of Mars. Science 306:1758-1761.

Fossing, H., Gallardo, V., Jørgensen, B.B., Hüttel, M., Nielsen, L.P., Schulz, H., Canfield, D.E., Forster, S., Glud, R.N., Gundersen, J.K., Küver, J., Ramsing, N.B., Teske, A., Thamdrup, B., and Ulloa, O. (1995) Concentration and transport of nitrate by the mat-forming sulphur bacterium Thioploca. Nature 373:713-715.

Franks, J. and Stolz, J.F. (2009) Flat laminated microbial mat communities. Earth-Science Reviews 96:163-172.

Gallardo, V.A. (1977) Large benthic microbial communities in sulphide biota under Peru-Chile subsurface counter current. Nature 286:331-332.

Garcia-Pichel, F., Mechling, M., and Castenholz, R.W. (1994) Diel migrations of microorganisms within a benthic, hypersaline mat community. Appl. Environ. Microbiol. 60:1500-1511. 
Garrity, G.M. (2005) Bergey's Manual of Systematic Bacteriology: The Proteobacteria, Springer, New York.

Gehling, J.G. (1999) Microbial mats in terminal Proterozoic siliciclastics; Ediacaran death masks. Palaios 14:40-57.

Gerdes, G., Klenke, T., and Noffke, N. (2000) Microbial signatures in peritidal siliciclastic sediments: a catalogue. Sedimentology 47:279-308.

Gill, F.L., Harding, I.C., Little, C.T.S., and Todd, J.A. (2005) Palaeogene and Neogene cold seep communities in Barbados, Trinidad and Venezuela: an overview Palaeogeogr., Palaeoclimatol., Palaeoecol. 227:191-209.

Goedert, J.L. and Kaler, K.L. (1996) A new species of Abyssochrysos (Gastropoda: Loxonematoidea) from a Middle Eocene cold-seep carbonate in the Humptulips Formation, western Washington. Velliger 39:65-70.

Goedert, J.L., Thiel, V., Schmale, O., Rau, W.W., Michaelis, W., and Peckmann, J. (2003) The Late Eocene "Whiskey Creek" methane-seep deposit (western Washington State). Facies 48:223-239.

Golubic, S. (1976) Organisms that build stromatolites. In Stromatolites, edited by M.R. Walter, Elsevier, Amsterdam, pp 113-126.

Graco, M., Farias, L., Molina, V., Gutierrez, D., and Nielsen, P.L. (2001) Massive developments of microbial mats following phytoplankton blooms in a naturally eutrophic bay: implications for nitrogen cycling. Limnol. Oceanogr. 46:821-832.

Grant, C.W. (1991) Lateral and vertical distributions of filamentous bacterial mats (Beggiatoa spp.) in Santa Barbara Basin, California: a modern analog for organic-rich facies of the Monterey Formation. M.S. thesis, California State University, Long Beach.

Greinert, J., Bohrmann, G., and Elvert, M. (2002) Stromatolitic fabric of authigenic carbonate crusts: result of anaerobic methane oxidation at cold seeps in $4,850 \mathrm{~m}$ water depth. International Journal of Earth Sciences 91:698-711.

Grotzinger, J.P. and Knoll, A.H. (1999) Stromatolites in Precambrian carbonates: evolutionary mileposts or environmental dipsticks? Annu. Rev. Earth Planet. Sci. 27:313-358.

Hagadorn, J.W. and Bottjer, D.J. (1997) Wrinkle structures: microbially mediated sedimentary structures common in subtidal siliciclastic settings at the Proterozoic-Phanerozoic transition. Geology 25:1047-1050.

Hagadorn, J.W. and Bottjer, D.J. (1999) Restriction of a Late Neoproterozoic biotope: suspect-microbial structures and trace fossils at the Vendian-Cambrian transition. Palaios 14:73-85.

Hedges, S.B., Battistuzzi, F.U., and Blair, J.E. (2006) Molecular timescale of evolution in the Proterozoic. In Neoproterozoic Geobiology and Paleobiology, edited by S. Xiao and A.J. Kaufmans, Springer, New York, pp 199-229.

Hinrichs, K.-U., Hayes, J.M., Sylva, S.P., Brewer, P.G., and DeLong, E.F. (1999) Methane-consuming archaebacteria in marine sediments. Nature 398:802-805.

Hinrichs, K.-U., Summons, R.E., Orphan, V., Sylva, S.P., and Hayes, J.M. (2000) Molecular and isotopic analysis of anaerobic methane-oxidising communities in marine sediments. Org. Geochem. 31:1685-1701.

Hofmann, H.J., Grey, K., Hickman, A.H., and Thorpe, R.I. (1999) Origin of $3.45 \mathrm{Ga}$ coniform stromatolites in the Warrawoona Group, Western Australia. GSA Bulletin 111:1256-1262.

Hovland, M. and Judd, A.G. (1988) Seabed Pockmarks and Seepages, Impact on Geology, Biology, and Marine Environments, Fraham and Trotman, Inc., London.

Howarth, R., Unz, R.F., Seviour, E.M., Seviour, R.J., Blackall, L.L., Pickup, R.W., Jones, J.G., Yaguchi, J., and Head, I.M.
(1999) Phylogenetic relationships of filamentous sulfur bacteria (Thiothrix spp. and Eikelboom type $021 \mathrm{~N}$ bacteria) isolated from wastewater-treatment plants and description of Thiothrix eikelboomii sp. nov., Thiothrix unzii sp. nov., Thiothrix fructosivorans sp. nov. and Thiothrix defluvii sp. nov. Int. J. Syst. Bacteriol. 49:1817-1827.

Hüttel, M., Forster, S., Klöser, S., and Fossing, H. (1996) Vertical migration in the sediment-dwelling sulfur bacteria Thioploca spp. in overcoming diffusion limitations. Appl. Environ. Microbiol. 62:1863-1872.

Jannasch, H.W., Nelson, D.C., and Wirsen, C.O. (1989) Massive natural occurrence of unusually large bacteria (Beggiatoa spp.) at a hydrothermal deep-sea vent site. Nature 342:834-836.

Jenkins, R.G., Hikida, Y., Chikaraishi, Y., Ohkouchi, N., and Tanabe, K. (2008) Microbially induced formation of ooid-like coated grains in the Late Cretaceous methane-seep deposits of the Nakagawa area, Hokkaido, northern Japan. Island Arc 17:261-269.

Jiang, G., Kennedy, M.J., and Christie-Blick, N. (2003) Stable isotopic evidence for methane seeps in Neoproterozoic postglacial cap carbonates. Nature 426:822-826.

Johnston, D.T., Wing, B.A., Farquhar, J., Kaufman, A.J., Strauss, H., Lyons, T.W., Kah, L.C., and Canfield, D.E. (2005) Active microbial sulfur disproportionation in the Mesoproterozoic. Science 310:1477-1479.

Jørgensen, B.B. (1977) Distribution of colorless sulfur bacteria (Beggiatoa-spp) in a coastal marine sediment. Mar. Biol. 41:19-28.

Joye, S.B., Boetius, A., Orcutt, B.N., Montoya, J.P., Schulz, H.N., Erickson, M.J., and Lugo, S.K. (2004) The anaerobic oxidation of methane and sulfate reduction in sediments from Gulf of Mexico cold seeps. Chem. Geol. 205:219-238.

Joye, S.B., Samarkin, V.A., Orcutt, B.N., MacDonald, I.R., Hinrichs, K.-U., Elvert, M., Teske, A.P., Lloyd, K.G., Lever, M.A., Montoya, J.P., and Meile, C.D. (2009a) Metabolic variability in seafloor brines revealed by carbon and sulphur dynamics. Nat. Geosci. 2:349-354.

Joye, S.B., Bowles, M.W., Samarkin, V.A., Hunter, K.S., and Niemann, H. (2009b) Biogeochemical signatures and microbial activity of different cold seep habitats along the Gulf of Mexico lower slope. Deep Sea Research (in press).

Kalanetra, K.M., Joye, S.B., Sunseri, N.R., and Nelson, D.C. (2005) Novel vacuolate sulfur bacteria from the Gulf of Mexico reproduce by reductive division in three dimensions. Environ. Microbiol. 7:1451-1460.

Kelly, D.P. (1971) Autotrophy: concepts of lithotrophic bacteria and their organic metabolism. Annu. Rev. Microbiol. 25:177-210.

Kelly, D.P. (1988a) Oxidation of sulfur compounds. In The Nitrogen and Sulfur Cycles, edited by J.A. Cole and S.J. Ferguson, pp 65-98.

Kelly, D.P. (1988b) Physiology and biochemistry of unicellular sulfur bacteria. In Autotrophic Bacteria, edited by H. Schlegel and B. Bowien, Science Tech Publishers, Madison, WI, pp 193218.

Knittel, K., Boetius, A., Lemke, A., Eilers, H., Lochte, K., Pfannkuche, O., Linke, P., and Amann, R. (2003) Activity, distribution, and diversity of sulfate reducers and other bacteria in sediments above gas hydrate (Cascadia margin, Oregon). Geomicrobiol. J. 20:269-294.

Knittel, K., Losekann, T., Boetius, A., Kort, R., and Amann, R. (2005) Diversity and distribution of methanotrophic archaea at cold seeps. Appl. Environ. Microbiol. 71:467-479.

Knoll, A.H. (1985) Exceptional preservation of photosynthetic organisms in silicified carbonates and silicified peats. Philos. Trans. R. Soc. Lond., B, Biol. Sci. 311:111-122. 
Knoll, A.H. (2008) Cyanobacteria and Earth history. In The Cyanobacteria: Molecular Biology, Genomics and Evolution, edited by A. Herrero and E. Floress, Caister Academic Press, pp 1-21.

Kolkwitz, R. (1909) Schizomycetes. Spaltpilze (Bacteria). In Kryptogamenflora der Mark Brandenburg, Leizpig, pp 1-186.

Kornberg, A. (1995) Inorganic polyphosphate-toward making a forgotten polymer unforgettable. J. Bacteriol. 177:491-496.

Krajewski, K.P., Van Cappellen, P., Trichet, J., Kuhn, O., Lucas, J., Martin-Algarra, A., Prévot, L., Tewari, V.C., Gaspar, L., Knight, R.I., and Lamboy, M. (1994) Biological processes and apatite formation in sedimentary environments. Eclogae Geologicae Helvetiae 87:701-745.

Krajewski, K.P., Leśniak, P.M., Łącka, B., and Zawidzki, P. (2000) Origin of phosphatic stromatolites in the Upper Cretaceous condensed sequence of the Polish Jura Chain. Sediment. Geol. 136:89-112.

Kring, D.A. and Abramov, O. (2005) Impact-induced hydrothermal activity on early Mars. J. Geophys. Res. 110, doi:10.1029/ 2005JE002453.

Krüger, M., Blumenberg, M., Kasten, S., Wieland, A., Känel, L., Klock, J.-H., Michaelis, W., and Seifert, R. (2008) A novel, multi-layered methanotrophic microbial mat system growing on the sediment of the Black Sea. Environ. Microbiol. 10:19341947.

Larkin, J.M. and Strohl, W.R. (1983) Beggiatoa, Thiothrix and Thioploca. Annual Reviews of Microbiology 37:341-367.

Larkin, J., Aharon, P., and Henk, M.C. (1994) Beggiatoa in microbial mats at hydrocarbon vents in the Gulf of Mexico and Warm Mineral Springs, Florida. Geo-Marine Letters 14:97-103.

Lein, A.Y. (2004) Authigenic carbonate formation in the ocean. Lithology and Mineral Resources 39:1-30.

Little, C.T.S., Glynn, S.E.J., and Mills, R.A. (2004) Four-hundredand-ninety-million-year record of bacteriogenic iron oxide precipitation at sea-floor hydrothermal vents. Geomicrobiol. J. 21:415-429.

Logan, B.W. (1961) Cryptozoan and associated stromatolites from the Recent, Shark Bay, Western Australia. J. Geol. 69:517533.

Lowe, D.R. (1994) Abiological origin of described stromatolites older than $3.2 \mathrm{Ga}$. Geology 22:387-390.

Ludwig, R., Al-Horani, F.A., De Beer, D., and Jonkers, H.M. (2005) Photosynthesis-controlled calcification in a hypersaline microbial mat. Limnol. Oceanogr. 50:1836-1843.

Maier, S. and Gallardo, V.A. (1984) Thioploca araucae sp. nov., and Thioploca chileae sp. nov. Int. J. Syst. Bacteriol. 34:414-418.

Matsumoto, R. (1990) Vuggy carbonate crust formed by hydrocarbon seepage on the continental shelf of Baffin Island, northeast. Geochem. J. 24:143-158.

Matthew, G.F. (1890) On the existence of organisms in the Precambrian rocks. Bulletin of the Natural History Society of New Brunswick 2:28-33.

McLoughlin, N., Wilson, L.A., and Brasier, M.D. (2008) Growth of synthetic stromatolites and wrinkle structures in the absence of microbes-implications for the early fossil record. Geobiology 6:95-105.

Michaelis, W., Seifert, R., Nauhaus, K., Treude, T., Thiel, V., Blumenberg, M., Knittel, K., Gieseke, A., Peterknecht, K., Pape, T., Boetius, A., Amann, R., Jørgensen, B.B., Widdel, F., Peckmann, J.R., Pimenov, N.V., and Gulin, M.B. (2002) Microbial reefs in the Black Sea fueled by anaerobic oxidation of methane. Science 297:1013-1015.

Moeller, M.M., Nielsen, L.P., and Jørgensen, B.B. (1985) Oxygen responses and mat formation by Beggiatoa spp. Appl. Environ. Microbiol. 50:373-382.
Monty, C.L.V. (1976) The origin and development of cryptalgal fabrics. In Stromatolites, edited by M.R. Walter, Elsevier, Amsterdam, pp 193-250.

Mußmann, M., Hu, F.Z., Richter, M., de Beer, D., Preisler, A., Jørgensen, B.B., Huntemann, M., Glockner, F.O., Amann, R., Koopman, W.J.H., Lasken, R.S., Janto, B., Hogg, J., Stoodley, P., Boissy, R., and Ehrlich, G.D. (2007) Insights into the genome of large sulfur bacteria revealed by analysis of single filaments. PLoS Biology 5:e230.

Nathan, Y., Bremner, J.M., Lowenthal, R.E., and Monteiro, P. (1993) Role of bacteria in phosphorite genesis. Geomicrobiol. J. 11:69-76.

Nauhaus, K., Boetius, A., Kruger, M., and Widdel, F. (2002) In vitro demonstration of anaerobic oxidation of methane coupled to sulphate reduction in sediment from a marine gas hydrate area. Environ. Microbiol. 4:296-305.

Nelson, D.C. and Castenholz, R.W. (1981) Use of reduced sulfur compounds by Beggiatoa sp. J. Bacteriol. 147:140-154.

Nelson, D.C. and Jannasch, H.W. (1983) Chemoautotrophic growth of a marine Beggiatoa in sulfide-gradient cultures. Arch. Microbiol. 136:262-269.

Newsom, H.E., Hagerty, J.J., and Thorsos, I.E. (2001) Location and sampling of aqueous and hydrothermal deposits in martian impact craters. Astrobiology 1:71-88.

Niemann, H., Lösekann, T., de Beer, D., Elvert, M., Nadalig, T., Knittel, K., Amann, R., Sauter, E.J., Schlüter, M., Klages, M., Foucher, J.P., and Boetius, A. (2006) Novel microbial communities of the Haakon Mosby mud volcano and their role as methane sink. Nature 443:854-858.

Nikolaus, R., Ammerman, J.W., and MacDonald, I.R. (2003) Distinct pigmentation and trophic modes in Beggiatoa from hydrocarbon seeps in the Gulf of Mexico. Aquat. Microb. Ecol. 32:85-93.

Nissenbaum, A. and Kaplan, I.R. (1966) Origin of the Be'eri (Israel) sulfur deposit. Chem. Geol. 1:295-316.

Noffke, N. (2008) Turbulent lifestyle: microbial mats on Earth's sandy beaches-today and 3 billion years ago. GSA Today 18:4-9.

Noffke, N., Hazen, R., and Nhleko, N. (2003) Earth's earliest microbial mats in a siliciclastic marine environment $(2.9 \mathrm{Ga}$ Mozaan Group, South Africa). Geology 31:673-676.

Noffke, N., Knoll, A.H., and Grotzinger, J.P. (2002) Sedimentary controls on the formation and preservation of microbial mats in siliciclastic deposits: a case study from the Upper Neoproterozoic Nama Group, Namibia. Palaios 17:533-544.

Omoregie, E.O., Mastalerz, V., de Lange, G., Straub, K.L., Kappler, A., Roy, H., Stadnitskaia, A., Foucher, J.-P., and Boetius, A. (2008) Biogeochemistry and community composition of iron- and sulfur-precipitating microbial mats at the Chefren mud volcano (Nile Deep Sea Fan, Eastern Mediterranean). Appl. Environ. Microbiol. 74:3198-3215.

Orphan, V.J., House, C.H., Hinrichs, K.U., McKeegan, K.D., and DeLong, E.F. (2001) Methane-consuming archaea revealed by directly coupled isotopic and phylogenetic analysis. Science 293:484-487.

Orphan, V.J., House, C.H., Hinrichs, K.U., McKeegan, K.D., and DeLong, E.F. (2002) Multiple archaeal groups mediate methane oxidation in anoxic cold seep sediments. Proc. Natl. Acad. Sci. U.S.A. 99:7663-7668.

Orphan, V.J., Ussler, W., Naehr, T.H., House, C.H., Hinrichs, K.U., and Paull, C.K. (2004) Geological, geochemical, and microbiological heterogeneity of the seafloor around methane vents in the Eel River Basin, offshore California. Chem. Geol. 205:265-289. 
Paerl, H.W., Steppe, T.F., and Reid, R.P. (2001) Bacterially mediated precipitation in marine stromatolites. Environ. Microbiol. 3:123-130.

Peckmann, J. and Goedert, J.L. (2005) Geobiology of ancient and modern methane-seeps. Palaeogeogr., Palaeoclimatol., Palaeoecol. 227:1-5.

Peckmann, J., Reimer, A., Luth, U., Luth, C., Hansen, B.T., Heinicke, C., Hoefs, J., and Reitner, J. (2001) Methane-derived carbonates and authigenic pyrite from the northwestern Black Sea. Mar. Geol. 177:129-150.

Peckmann, J., Goedert, J.L., Thiel, V., Michaelis, W., and Reitner, J. (2002) A comprehensive approach to the study of methaneseep deposits from the Lincoln Creek Formation, western Washington State USA. Sedimentology 49:855-873.

Peckmann, J., Thiel, V., Reitner, J., Taviani, M., Aharon, P., and Michaelis, W. (2004) A microbial mat of a large sulfur bacterium preserved in a Miocene methane-seep limestone Geomicrobiol. J. 21:247-255.

Pierson, B.K., Bauld, J., Castenholz, R.W., D'Amelio, E., Des Marais, D.J., Farmer, J.D., Grotzinger, J.P., Jørgensen, B.B., Nelson, D.C., Palmisano, A.C., Schopf, J.W., Summons, R.E., Walter, M.R., and Ward, D.M (1992) Modern mat-building microbial communities: a key to the interpretation of Proterozoic stromatolitic communities. In The Proterozoic Biosphere: a Multidisciplinary Study, edited by J.W. Schopf and C. Klein, Cambridge University Press, Cambridge, pp 245-342.

Pitts, G., Allam, A.I., and Hollis, J.P. (1972) Beggiatoa: occurrence in the rice rhizosphere. Science 178:990-992.

Popa, R., Kinkle, B.K., and Badescu, A. (2004) Pyrite framboids as biomarkers for iron-sulfur systems. Geomicrobiol. J. 21:193206.

Rabus, R., Hansen, T.A., and Widdel, F. (2006) Dissimilatory sulfate- and sulfur-reducing prokaryotes. In The Prokaryotes: an Evolving Electronic Resource for the Microbiological Community, edited by M. Dworkin, S. Falkow, E. Rosenberg, K.H. Schleifer, and E. Stackebrandts, Springer-Verlag, New York, pp 659768.

Reeburgh, W.S. (1976) Methane consumption in Cariaco Trench waters and sediments. Earth Planet. Sci. Lett. 28:337-344.

Reichenbach, H., Ludwig, W., and Stackebrandt, E. (1986) Lack of relationship between gliding cyanobacteria and filamentous gliding heterotrophic eubacteria: comparison of $16 \mathrm{~S}$ rRNA catalogues of Spirulina, Saprospira, Vitreoscilla, Leucothrix, and Herpetosiphon. Arch. Microbiol. 145:391-395.

Reid, R.P., Visscher, P.T., Decho, A.W., Stolz, J.F., Bebout, B.M., Dupraz, C., MacIntyre, I.G., Paerl, H.W., Pinckney, J.L., Prufert-Bebout, L., Steppe, T.F., and DesMarais, D.J. (2000) The role of microbes in accretion, lamination and early lithification of modern marine stromatolites. Nature 406:989-992.

Reilly, J.F., II, MacDonald, I.R., Biegert, E.K., and Brooks, J.M. (1996) Geologic controls on the distribution of chemosynthetic communities in the Gulf of Mexico. In Hydrocarbon Migration and Its Near-Surface Expression: American Association of Petroleum Geologists Memoir 66, edited by D. Schumacher and M.A. Abrams, American Association of Petroleum Geologists, Tulsa, OK, pp 39-62.

Reimers, C., Kastner, M., and Garrison, R.E. (1990) The role of bacterial mats in phosphate mineralization wth particular reference to the Monterey Formation. In Phosphate Deposits of the World. Volume 3: Neogene to Modern Phosphorites, edited by W.C. Burnett and S.R. Riggs, Cambridge University Press, Cambridge, pp 300-311.

Reysenbach, A.L., Götz, D., Banta, A., Jeanthon, C., and Fouquet, Y. (2002) Expanding the distribution of the Aquificales to the deep-sea vents on Mid-Atlantic Ridge and Central Indian Ridge. Cah. Biol. Mar. 43:425-428.

Ritger, S., Carson, B., and Suess, E. (1987) Methane-derived authigenic carbonates formed by suduction-induced pore-water expulsion along the Oregon/Washington margin. Geol. Soc. Am. Bull. 98:147-156.

Robertson, L.A. and Kuenen, J.G. (2006) The colorless sulfur bacteria. In The Prokaryotes, edited by M. Dworkin, S. Falkow, E. Rosenberg, K.-H. Schleifer, and E. Stackebrandts, Springer, New York, pp 985-1011.

Sayama, M. (2001) Presence of nitrate-accumulating sulfur bacteria and their influence on nitrogen cycling in a shallow coastal marine sediment. Appl. Environ. Microbiol. 67:3481-3487.

Schieber, J., Bose, P., Eriksson, P.G., Banderjee, S., Sarkar, S., Altermann, W., and Catuneanu, O. (2007) Atlas of Microbial Mat Features Preserved within the Silclastic Rock Record, Elsevier, Amsterdam.

Schmidt, A.R. and Schäfer, U. (2005) Leptotrichites resinatus new genus and species: a fossil sheathed bacterium in Alpine Cretaceous amber. J. Paleontol. 79:175-184.

Schmidt, T.M., Arieli, B., Cohen, Y., Padan, E., and Strohl, W.R. (1987) Sulfur metabolism of Beggiatoa alba. J. Bacteriol. 169:5466-5472.

Schulz, H.N. (2006) The genus Thiomargarita. In The Prokaryotes: An Evolving Electronic Resource for the Microbiological Community, edited by M. Dworkin, S. Falkow, E. Rosenberg, K.H. Schleifer, and E. Stackebrandts, Springer-Verlag, New York, pp 1156-1163.

Schulz, H.N. and Jørgensen, B.B. (2001) Big bacteria. Annu. Rev. Microbiol. 55:2001.

Schulz, H.N. and Schulz, H.D. (2005) Large sulfur bacteria and the formation of phosphorite. Science 307:416-418.

Schulz, H.N., Jørgensen, B.B., Fossing, H., and Ramsing, N.B. (1996) Community structure of filamentous, sheath-building sulfur bacteria, Thioploca spp., off the coast of Chile. Appl. Environ. Microbiol. 62:1855-1862.

Schulz, H.N., Brinkhoff, T., Ferdelman, T., Marine, M.H., Teske, A., and Jørgensen, B.B. (1999) Dense populations of a giant sulfur bacterium in Namibian shelf sediments. Science 284:493-495.

Schulz, H.N., Strotmann, B., Gallardo, V.A., and Jørgensen, B.B. (2000) Population study of the filamentous sulfur bacteria Thioploca spp. off the Bay of Concepcion, Chile. Mar. Ecol. Prog. Ser. 200:117-126.

Scotten, H.L. and Stokes, J.L. (1962) Isolation and properties of Beggiatoa. Arch. Microbiol. 42:353-368.

Shapiro, R.S. (2004) Recognition of fossil prokaryotes in Cretaceous methane seep carbonates: relevance to astrobiology. Astrobiology 4:438-449.

Sibuet, M., Juniper, S.K., and Pautot, G. (1988) Cold-seep benthic communities in the Japan subduction zones: geological control of community development. J. Mar. Res. 46:333-348.

Smith, C.R., Kukert, H., Wheatcroft, R.A., Jumars, P.A., and Deming, J.W. (1989) Vent fauna on whale remains. Nature 341:27-28.

Sommer, S., Gutzmann, E., Ahlrichs, W., and Pfannkuche, O. (2003) Rotifers colonizing sediments with shallow gas hydrates. Naturwissenschaften 90:273-276.

Soudry, D. and Champetier, Y. (1983) Microbial processes in the Negev phosphorites (southern Israel). Sedimentology 30:411423.

Soudry, D. (2000) Microbial phosphate sediment. In Microbial Sediments, edited by R.E. Riding and S.M. Awramik, SpringerVerlag, New York, pp 127-136. 
Soutar, A. and Crill, P.A. (1977) Sedimentation and climatic patterns in the Santa Barbara Basin during the $19^{\text {th }}$ and $20^{\text {th }}$ centuries. Geol. Soc. Am. Bull. 88:1161-1172.

Squires, R.L. (1995) First fossil species of the chemosyntheticcommunity gastropod Provanna: localized cold-seep limestones in upper Eocene and Oligocene rocks, Washington. Velliger 38:30-36.

Stakes, D.S., Orange, D., Paduan, J., Salamy, K., and Maher, N. (1999) Origin of authigenic cold seep carbonates from Monterey Bay. Mar. Geol. 159:93-109.

Stal, L.J. (2000) Cyanobacterial mats and stromatolites. In The Ecology of Cyanobacteria, edited by B.A. Whitton and M. Potts, Kluwer Academic Publishers, Dordrect, the Netherlands, pp 61-120.

Steudel, R., Holdt, G., Göbel, T., and Hazeu, W. (1987) Chromatographic separation of higher polythionates $\mathrm{S}_{\mathrm{n}} \mathrm{O}_{2-6}$ $(\mathrm{n}=3 \ldots 22)$ and their detection in cultures of Thiobacillus ferrooxidans: molecular composition of bacterial sulfur secretions. Angew. Chem. Int. Ed. Engl. 26:151-153.

Strohl, W.R. and Larkin, J.M. (1978) Enumeration, isolation, and characterization of Beggiatoa from freshwater sediments. Appl. Environ. Microbiol. 36:755-770.

Summons, R.E., Jahnke, L.L., Hope, J.M., and Logan, G.A. (1999) 2-Methylhopanoids: molecular fossils for cyanobacteria recording a geological history of oxygenic photosynthesis. Nature 400:554-557.

Taviani, M. (1994) The "calcari a Lucina" macrofauna reconsidered: deep-sea faunal oases from Miocene-age cold vents in the Romagna Apennine, Italy. Geo-Marine Letters 14:185-191.

Taylor, C.D., Wirsen, C.O., and Gaill, F. (1999) Rapid microbial production of filamentous sulfur mats at hydrothermal vents. Appl. Environ. Microbiol. 65:2253-2255.

Teichert, B.M.A., Bohrmann, G., and Seuss, E. (2005) Chemoherms on Hydrate Ridge- unique microbially mediated carbonate build-ups growing into the water column. Palaeogeogr., Palaeoclimatol., Palaeoecol. 227:67-85.

Teske, A. and Nelson, D.C. (2006) The genera Beggiatoa and Thioploca. In The Prokaryotes, edited by M. Dworkin, S. Falkow, E. Rosenberg, K.H. Schleifer, and E. Stackebrandts, Springer-Verlag, New York, pp 784-810.

Thar, R. and Fenchel, T. (2005) Survey of motile microaerophilic bacterial morphotypes in the oxygen gradient above a marine sulfidic sediment Appl. Environ. Microbiol. 71:3682-3691.

Thar, R. and Kühl, M. (2002) Conspicuous veils formed by vibroid bacteria on sulfidic marine sediment. Appl. Environ. Microbiol. 68:6310-6320.

Thiel, V., Peckmann, J., Richnow, H.H., Luth, U., Reitner, J., and Michaelis, W. (2001) Molecular signals for anaerobic methane oxidation in Black Sea seep carbonates and microbial mat. Mar. Chem. 73:97-112.

Toner, B.M., Santellia, S.M., Marcus, M.A., Wirth, R., Chan, C.S., McCollom, T., Bach, W., and Edwards, K.J. (2009) Biogenic iron oxyhydroxide formation at mid-ocean ridge hydrothermal vents: Juan de Fuca Ridge. Geochim. Cosmochim. Acta 73:388-403.

Trela, W. (2008) Sedimentary and microbial record of the Middle/ Late Ordovician phosphogenetic episode in the northern Holy Cross Mountains, Poland. Sediment. Geol. 203:131-142.

Treude, T., Boetius, A., Knittel, K., Wallmann, K., and Jørgensen, B.B. (2003) Anaerobic oxidation of methane above gas hydrates at Hydrate Ridge, NE Pacific Ocean. Mar. Ecol. Prog. Ser. 264:1-14.
Treude, T., Knittel, K., Blumenberg, M., Seifert, R., and Boetius, A. (2005) Subsurface microbial methanotrophic mats in the Black Sea. Appl. Environ. Microbiol. 71:6375-6378.

Treude, T., Orphan, V., Knittel, K., Gieseke, A., House, C.H., and Boetius, A. (2007) Consumption of methane and $\mathrm{CO}_{2}$ by methanotrophic microbial mats from gas seeps of the anoxic Black Sea. Appl. Environ. Microbiol. 73:2271-2283.

Trewin, N.H. and Knoll, A. (1999) Preservation of Devonian chemotrophic filamentous bacteria in calcite veins. Palaios 14:288-294.

Tryon, M.D. and Brown, K.M. (2001) Complex flow patterns through Hydrate Ridge and their impact on seep biota. Geophys. Res. Lett. 28:2863-2866.

van Dongen, B.E., Roberts, A.P., Schouten, S., Jiang, W-T., Florindo, F., and Pancost, R.D. (2007) Formation of iron sulfide nodules during anaerobic oxidation of methane. Geochim. Cosmochim. Acta 71:5155-5167.

Van Dover, C.L., German, C.R., Speer, K.G., Parson, L.M., and Vrijenhoek, R.C. (2002) Evolution and biogeography of deepsea vent and seep invertebrates. Science 295:1253-1257.

Vaucher, J.P. (1803) Histoire des Conferves d'eau douce, contenant leurs différens modes de réproduction, et la déscription de leurs principales espéces, Geneva.

Visscher, P.T., Reid, R.P., and Bebout, B.M. (2000) Microscale observations of sulfate reduction: correlation of microbial activity with lithified micritic laminae in modern marine stromatolites. Geology 28:919-922.

Walcott, C.D. (1883) Pre-Carboniferous strata of the Grand Canyon of Colorado. Am. J. Sci. 26:437-442.

Walter, M.R., Buick, R., and Dunlop, J.S.R. (1980) Stromatolites, 3400-3500 Myr old from the North Pole area, Western Australia. Nature 284:443-445.

Wentzien, S., Sand, W., Albertsen, A., and Steudel, R. (1994) Thiosulfate and tetrathionate degradation as well as biofilm generation by Thiobacillus intermedius and Paracoccus versutus studied by micro-calometry, HPLC, and ion-pair chromatography. Arch. Microbiol. 161:116-125.

Williams, L.A. (1984) Subtidal stromatolites in Monterey Formation and other organic-rich rocks as suggested contributors to petroleum formation. Am. Assoc. Pet. Geol. Bull. 68:18791893.

Williams, L.A. and Reimers, C. (1983) Role of bacterial mats in oxygen-deficient marine basins and coastal upwelling regimes: preliminary report. Geology 11:267-269.

Wirsen, C.O., Sievert, S.M., Cavanaugh, C.M., Molyneaux, S.J., Ahmad, A., Taylor, L.T., DeLong, E.F., and Taylor, C.D. (2002) Characterization of an Autotrophic sulfide-oxidizing marine Arcobacter sp. that produces filamentous sulfur. Appl. Environ. Microbiol. 68:316-325.

Wood, A.P. and Kelly, D.P. (1986) Chemolithotrophic metabolism of the newly isolated moderately thermophilic, obligately autotrophic Thiobacilus tepidarius. Arch. Microbiol. 144:71-77.

Address correspondence to: Jake V. Bailey

Division of Geological and Planetary Sciences California Institute of Technology 1200 East California Blvd. MC100-23

Pasadena, California 91125

E-mail: jvbailey@caltech.edu 
